\title{
CRÍTICA DA REPRESENTAÇÃO E CRÍTICA DO CAPITALISMO: FILOSOFIA, ARTE E PRÁXIS EM THEODOR ADORNO
}

\author{
Pedro Rocha de Oliveira \\ Universidade Federal de Juiz de Fora
}

\begin{abstract}
This essay highlights the role played by the Marxian notions of exchange, abstract labour and technological-productive potential in the Adornian theories of conceptual representation, philosophy of history and aesthetics. The immanent analysis of several relevant passages from the Negative Dialectics, the Dialectics of Enlightenment and the Aesthetic Theory is undertaken, while a continuous argumentation is constructed, emphasising the consistency of the intellectual project that Adorno deploys in those works.

Keywords: Theodor Adorno, Karl Marx, dialectics, philosophy of history, aesthetics, praxis.

Resumo: 0 presente texto sublinha o papel que as noções marxianas de troca, trabalho abstrato e potencial tecnológico-produtivo desempenham nas teorias adornianas sobre a representação conceitual, a filosofia da história e a estética. É empreendida a análise imanente de trechos relevantes da Dialética Negativa, da Dialética do Esclarecimento e da Teoria Estética, buscando construir uma argumentação contínua que salienta o caráter unificado do projeto intelectual que Adorno desenvolve nessas obras.
\end{abstract}

Palavras-chave: Theodor Adorno, Karl Marx, dialética, filosofia da história, estética, praxis.

\section{Introdução}

Theodor Adorno havia planejado adotar como mote da sua Teoria Estética, publicada postumamente, a observação, da autoria de Friedrich 
Schlegel, de que "àquilo que se chama filosofia da arte normalmente falta uma das duas coisas, ou a filosofia ou a arte" (TE $366 / 544)^{1}$. Essa sentença evoca o problema central da obra anterior de Adorno, a Dialética Negativa: a filosofia geralmente tende ou bem a impor-se sobre os objetos, sufocandoos sob um sistema autocentrado que precisa aparecer como algo isento de defeitos e brechas, impecável, ou bem a fetichisar seus objetos, em uma tentativa artificial de emprestá-los, desde fora de si mesmos, e desde dentro da filosofia, uma prioridade. O projeto da Dialética Negativa, assim, é deixar com que a filosofia transite no único meio em que ela pode circular sem problemas - ela mesma -, mas preservando a consciência da autolimitação que, assim, lhe é imposta, e que a condena a uma "implacável crítica de si mesma" (DN 15) ${ }^{2}$, como coloca Adorno. Mas a representação que se denuncia enquanto tal é também o objeto da Teoria Estética, uma vez que a obra expõe uma preocupação fundamental com o modernismo artístico que, afastando-se do realismo, fez da exibição - e mesmo da denúncia - do caráter de aparência da arte seu motivo e conteúdo maiores. Para fazer justiça ao pensamento de Adorno e, o que é mais importante, à sua significância objetiva, à maneira como ele se relaciona com o mundo, é preciso entender como e porque a arte e o conhecimento podem ser caracterizados e criticados a partir de um problema único.

\section{Problema abstrato da representação: dialética negativa}

$\mathrm{O}$ argumento que diz respeito à necessidade da filosofia de criticar a si mesma é bastante direto, embora repetido sob a forma de incontáveis formulações na Dialética Negativa. Uma delas diz que "o termo [dialética] não expressa nada além do fato de que os objetos não desaparecem em seus conceitos" (DN 16). A adequação entre o discurso e o seu objeto é sempre

\footnotetext{
${ }^{1}$ As citações da Teoria Estética de Adorno serão apresentadas no corpo do texto, entre parênteses, sendo a abreviatura do título da obra seguida pela paginação da edição de língua inglesa (T. W. Adorno: Aesthetic Theory. Trad.: R. Hullot-Kentor. Minneapolis: University of Minnesota Press, 1997) e pela paginação da edição alemã das obras completas (T. W. Adorno: Ästhetische Theorie. Gesammelte Schriften 7. Frankfurt am Main: Suhrkamp Verlag, 1986). As citações foram preparadas traduzindo-se 0 original alemão com amparo da inspiradora tradução de Hullot-Kentor.

${ }^{2}$ As citações da Dialética Negativa serão apresentadas no corpo do texto, entre parênteses, sendo a abreviatura do título da obra seguida pela paginação da edição das obras completas (ver nota anterior; Gesammelte Schriften 6).
} 
imperfeita, pela simples razão de que o discurso é algo outro que o objeto a respeito do qual ele discursa. Se o objeto do conhecimento, por definição, é inevitavelmente aquele que, para começar, não é conhecido, o conhecimento a ser construído a seu respeito será, evidentemente, qualitativamente diferente dele ${ }^{3}$. Isso afeta todo tipo de discurso; o esforço de lidar com a natureza da arte através da filosofia não é exceção. Contudo, não há outra forma de conhecer o objeto que não através de um discurso que, sendo diferente dele, deve com ele relacionar-se, ainda que de forma tensa.

Desde a noção kantiana de uma "coisa em si” - aquilo (seja lá o quê) que está além do nosso conhecimento possível - a tradição do Idealismo Alemão, com a qual o pensamento adorniano está enlaçado em combate interminável, já conhecia esse paradoxo dos paradoxos. Hegel, com a astuciosa abordagem da sua maturidade, resolveu-o através da hipóstase da Idéia, sujeito-objeto do filosofar, enquanto "identidade entre identidade e não-identidade", ou "idéia da unidade do conceito com seu objeto" Colocando as coisas nesses termos, Hegel apagou por decreto a diferença entre a alteridade e a diferença, ao mesmo tempo afirmando que esse ato é a própria essência do conhecimento. Ao colocar uma ênfase exclusiva no elemento de identidade da relação entre o discurso e seu objeto, Hegel transformou a relação em uma não-relação: numa imediatidade. E uma vez que essa manobra é, ela mesma, realizada por um discurso a respeito do que é o conhecimento, pode-se dizer que, em última análise, a identificação operada é aquela entre o discursivo e o não-discursivo, o objeto e o conceito.

Mas há dois níveis de discurso envolvidos: o primeiro é o do conhecimento sobre o objeto; o segundo, o do conhecimento sobre o conhecimento sobre o objeto ${ }^{6}$. Esse segundo nível assevera que o primeiro é inteiramente adequado ao seu objeto. É esse comentário legitimador que faz com que o Hegel da Lógica se qualifique ao epíteto de idealista, no sentido

\footnotetext{
3 Esse aspecto negativo da produção do conhecimento já está contido nos argumentos introdutórios da Fenomenologia do Espírito de Hegel (C.f. $\S \S 73,76)$.

${ }^{4}$ Ciência da Lógica \$112.

${ }^{5}$ Enciclopédia das Ciências Filosóficas, Parte I, §231.

${ }^{6}$ Adorno se refere a esse segundo nível como o domínio de "atos identificadores que julgam se 0 conceito faz justiça àquilo com que está lidando." (DN 149)
} 
difamador do termo: trata-se de uma estratégia que tenta dissolver através do discurso um problema que estava dado na relação entre o discurso e o não-discurso, o conhecimento e seu objeto. O termo "ideologia" em sua conotação crítico-negativa, descreve adequadamente esse comentário legitimador. E na medida que a dialética negativa, de acordo com a definição mencionada acima - e entendida não como um livro, mas como um procedimento de pensamento ${ }^{7}$ - é o reconhecimento da diferença entre o conhecimento e o seu objeto, ela se oferece como uma crítica da ideologia. Ademais, ela poderia - se valesse a pena - ser qualificada como uma crítica materialista da ideologia, pois o que ela oferece não é uma reflexão a respeito da natureza do pensamento e do discurso, mas uma recusa a basearse em uma tal reflexão uma vez que se trata de dar prioridade a um objeto que, no fim das contas, permanecerá externo ao pensamento e, no fundo, indiferente a ele ${ }^{8}$.

Este caráter materialista da crítica da ideologia promovida pela dialética negativa deve ser enfatizado de modo a separar essa última de uma teoria do conhecimento ${ }^{9}$ - desta perspectiva isenta sobre o conhecimento que, desde o ponto de vista da Fenomenologia do Espírito, o próprio Hegel já havia dispensado ${ }^{10}$. A questão da obra de Adorno não é epistemológica não é um recuo a um ponto de vista pré-hegeliano ou kantiano sobre as limitações que o conhecimento se impõe desde um nível transcendental. Esse nível transcendental, que, para Kant, era o objeto de um tipo especial de conhecimento, não está isento da autocrítica puramente destrutiva que a dialética negativa desencadeia ${ }^{11}$. $\mathrm{O}$ argumento de Adorno contra Kant parte da concepção hegeliana de que o criticismo, enquanto uma defesa da capacidade da razão de limitar a si mesma, é, na verdade, uma forma disfarçada de dizer que a razão é o seu próprio limite, ou seja, que a razão é o absoluto. De modo que, da mesma forma que Hegel, Adorno reconhece

\footnotetext{
${ }^{7}$ Algo de que procurei tratar em minha dissertação de mestrado, Dialética negativa como perspectiva para o pensamento (Rio de Janeiro: PUC-Rio, 2005), Capítulo 4, pp. 181-225.

${ }^{8}$ C.f. "'Logik des Zerfalls"' (“'Lógica da Desagregação"'), DN 148-9.

${ }_{9}^{9}$ Mais ou menos na mesma linha que será desenvolvida aqui poder-se-ía - se isso fosse interessante construir um argumento que separasse a velha Escola de Frankfurt - a geração de Adorno, Marcuse, Horkheimer - da nova - Habermas, Bürger, Honneth, etc.

${ }^{10}$ C.f. Introdução da Fenomenologia do Espírito, especialmente §73-6.

${ }^{11}$ Adorno discutirá um pouco isso aí na seção 1 da parte 3 da Dialética Negativa, a "Metacrítica da razão Prática".
} 
no discurso uma certa espontaneidade sem limites; mas, ao contrário de Hegel, ele não condena o idealismo recalcitrante de Kant por sua falta de poder criativo auto-consciente, mas pela reificação de suas próprias categorias - as estruturas a priori do conhecimento - enquanto traços inescapáveis que estão além de toda crítica - uma vez que eles mesmos, de fato, são oferecidos como resultados da crítica: "o poder da consciência é tão estendido que ele alcança até o logro dela própria" (DN 152). Neste sentido, a Dialética Negativa está tão longe quanto possível de uma coleção de observações metodológicas a respeito de como pensar. Pois o método funciona como aquele nível de discurso que prepara para o conhecimento propriamente dito, mas desaparece atrás dele assim que ele é empreendido, enquanto que, na dialética negativa, a consciência de que os conceitos e os objetos são necessariamente diferentes entre si - de que, além do daquilo sobre o que ele fala, há mais no discurso: sua própria aparência, seu caráter de apresentação ${ }^{12}$ - e que, portanto, o ato de dizer não pode ser apagado pelo que é dito, corre em sentido contrário à indulgência que aceita que uma parte do discurso saia de seu próprio fluxo, torne-se um ponto cego e ganhe o estatuto legitimador de pré-discurso. A espontaneidade absoluta do pensamento, que resulta de sua autocentralidade em sua própria aparência, portanto, ao contrário daquela vislumbrada por Hegel, é tal que mantém a si mesma apenas na medida que é incapaz de abranger aquilo que o pensamento não é, o que está do lado de fora dele, de tal modo que "contra o domínio total do método, a filosofia [que a dialética negativa quer sugerir] retém, corretivamente, um momento de jogo, o qual a tradição da cientifização gostaria de expulsar" (DN 26).

Pode ser que toda essa abordagem tenha ainda mais em comum com o pensamento pós-moderno da diferença do que pode aparentar. Entretanto, aquilo que em Adorno se oferece como uma crítica avant la lettre do fenômeno pós-moderno também não é muito difícil de ver. A falta de uma postura metodológica autônoma não é equivalente à multiplicidade ou (má) infinitude de pontos de vista com respeito ao pensamento: tanto essa multiplicidade quanto o método são mantidas em cheque pela atenção enfática à marginalidade do pensamento com respeito ao objeto, que permanece fora dele (DN 44). A crença pós-moderna de que os objetos

${ }^{12}$ C.f. "Darstellung" ("Apresentação"), DN 29-31. 
deveriam estar intrínseca e imediatamente abertos a múltiplas determinações e interpretações consiste, desde essa ótica, em uma tentativa ideológica de acabar com a separação entre objetos e pensamento ${ }^{13}$. Em oposição a isso, na Dialética Negativa é a opacidade e a externalidade do objeto que sugerem ao pensamento um caráter de brincadeira, a qual, entretanto, tem dois lados: enquanto dialética negativa, ela interfere na hermeticidade aparente do pensamento sistemático de modo a exibir como a consistência monolítica da argumentação coercitiva é, na verdade, o produto não da ação de conceitos esclarecedores que revelam como as coisas são, mas de uma aglutinação de pontos cegos em constelações de concepções reificadas ${ }^{14}$. Em suas análises da filosofia heideggeriana do ser, e da teoria kantiana a priori da percepção e da racionalidade prática ${ }^{15}$, Adorno mostra, então, como o conteúdo histórico-ideológico da vida social entra no pensamento e o determina sempre que ele tenta apresentar-se como autônomo e envolver seus produtos com a aura da autarquia. Por outro lado, esse caráter lúdico é a mímese, um conhecimento através de processos discursivos que não se aniquilam a si próprios em face do que veiculam, nem tentam oferecer-se em substituição aos seus objetos, mas apresentam a si mesmos junto com seus objetos - discursos que, enquanto imitações de objetos, funcionam também, eles mesmos, como objetos.

\footnotetext{
${ }^{13}$ Essa tentativa, de fato, termina tendo conseqüências nefastas para um pensamento político, uma vez que se perde a distância crítica entre o discurso e a realidade. Com isso, a luta política real acaba sendo tristemente confundida com uma luta por símbolos, sentidos e significados, e, conforme Terry Eagleton observa, permanece sempre alheia a uma crítica de base de como a sociedade funciona economicamente. A tendência, inclusive, é que a crítica da economia seja ela mesma encarada como mais um mero discurso totalizante. (C.f. Eagleton, Terry: "Capitalism, Modernism and Postmodernism" in New Left Review I/152, July-August 1985).

14 C.f. "'Logik des Zerfalls', ND 148-149. É paradoxal a relação entre essa perspectiva e a crítica esclarecida tradicional (idealista ou materialista) à ideologia. Por um lado, está em questão a crítica de pensamentos que já estão pensados - ou seja, a crítica do que, antigamente, se chamava de senso comum. Por outro lado, a dialética negativa envolve precisamente o oposto de uma elaboração conceitual per se, na medida que o que ela faz é se voltar contra os conceitos. 0 conceito é "aquilo que inicialmente opõe-se ao pensamento" (c.f. "Zur Dialektik der Identität" ("Sobre a Dialética da Identidade"), DN 149). Conforme Adorno coloca no parágrafo sobre a "lógica da desagregação", "no processo de desmitologização, a positividade tem que ser negada até chegar à razão instrumental que é posta pela própria desmitologização" (DN 148). Esse paradoxo será clarificado - ao mesmo tempo em que se espalha por todos os lados - em seguida, quando a discussão passar das desoladas e congeladas paragens da antimetodologia para os perímetros escaldantes e desolados da crítica cultural.

${ }^{15}$ Respectivamente, a segunda seção da Parte I da Dialética Negativa, intitulada "Ser e Existência", diversos parágrafos na Parte II ("Conceitos e Categorias") e o primeiro "Modelo" da Parte III, a já citada "Metacrítica da razão Prática".
} 
Tal descrição seria obrigada a considerar processos individuais de pensamento como fenômenos históricos. Desde este ponto de vista, é possível entender os objetos de acordo com duas dimensões diferentes: de um lado, estão os produtos discursivos do pensamento, ou seja, os resultados de um ato de discurso; do outro, estão os objetos desse discurso, os quais, entretanto, aparecem, agora, como produtos de algo que, por um lado, também se apresenta como um processo (ou seja, as coisas não vêm do nada) mas que, por outro lado, deve ser um processo cego e sem-sentido, uma vez que o discurso, o ponto de vista que dá visibilidade e empresta $o$ sentido, deve ser necessariamente outro que ele e diferente dele. Em outros termos: o discurso é sempre o discurso de algo que já estava lá antes. Tratase de uma lição hegeliana: para que o discurso tenha um conteúdo, para que ele diga algo sobre algo, e até para que ele negue algo, esse algo tem que estar lá anteriormente e oferecer alguma espécie de resistência contra o discurso $^{16}$; precisa ter um conteúdo específico diferente daquele do discurso que o afirmará ou negará: caso contrário, em que consistiria o próprio ato de dizer algo? Um discurso emancipatório a respeito do gênero, por exemplo, só pode ser eficaz e significativo - mesmo, e especialmente, quando entendemos essa eficácia e significância em termos de alguma construção discursiva do gênero - se ele for direcionado contra um ponto de partida histórico que permanece como uma referência estática em contraste com a qual o conteúdo emancipatório vai se delinear de forma problemática: possivelmente, um ponto de referência repulsivo - o machismo -, mas cuja existência é aceita e presumida pela crítica. Mas o caráter estático desse ponto de referência, de certa maneira, é seu caráter necessariamente ideológico: o que quer que apareça enquanto um objeto do conhecimento, por estar lá antes do conhecimento, aparece como algo que se auto-justifica. O que é histórico, desde esse ângulo, aparece dotado desse caráter espontaneamente mistificador de estar lá simplesmente, como se os acontecimentos do passado fossem suficientes, enquanto tais, para justificar e legitimar o que existe hoje, segundo uma estrutura perceptiva que, aparentemente, foi inculcada pelo treinamento civilizatório na causalidade

${ }^{16}$ C.f. "Unauflöslichkeit des Etwas" ("Indissolubilidade do Algo"), ND 139-140. Ver, também, a mecânica do Capítulo 1 da Fenomenologia do Espírito - e, de fato, a do livro como um todo. 
física $^{17}$. Na medida que o discurso tem um elemento intrinsecamente destrutivo e crítico - aquele que se volta contra o objeto, na afirmação de sua diferença frente a eles e por cima deles -, ele parece conter um momento de negação da própria história. $\mathrm{O}$ conhecimento pode ou não funcionar de acordo com esse elemento destrutivo. Assim, o saber sobre um objeto - um objeto histórico - pode ou bem ser a reafirmação da cegueira histórica do simplesmente dado - no caso de um processo de conhecimento formalmente conservador que se anula enquanto tal - ou bem ser uma crítica dessa historicidade - na medida que o resultado do conhecimento é visivelmente distinto do objeto conforme se encontrava antes e, ao mesmo tempo, se apropria da verdade desse objeto, ou pretende dizer o que ele é, como ele é, por que ele é. A crítica da historicidade do objeto é a apropriação pelo discurso - ou seja, uma problematização formalmente pública - dos processos que o produziram, os quais, por um lado, devem ser vistos como objetivos - anteriores ao conhecimento e independentes dele mas, por outro lado, são menos significativos e importantes do que aquilo que o conhecimento oferece como conteúdo de verdade. O conteúdo do conhecimento, ao mesmo tempo que faz aparecer o conteúdo da história enquanto tal, desafia esse conteúdo, nem que seja unicamente porque, a partir do momento que aparece o conhecimento, o mero objeto extracognitivo vira coisa do passado.

O voltar-se contra a história é, assim, um voltar-se contra a ideologia, em certo sentido, mas contra um tipo de ideologia que não é nem aquele do método supostamente isento de Kant nem aquele da asseveração de segunda ordem de Hegel. Não se trata de uma crítica ao idealismo legitimador, mas ao objetivismo, o qual tenta realizar o mesmo que aquele idealismo, mas através de um apelo ao óbvio ululante, ou seja, prescindindo do comentário que absolve o saber através de sua apologia mais ou menos loquaz. O conhecimento que se volta contra a história se volta contra a legitimização daquilo que acontece ou do que é simplesmente porque acontece ou é. Na medida que aponta para além do existente, o conhecimento assim concebido e empreendido tem um conteúdo utópico.

${ }^{17}$ Hegel, de fato, chama esse momento acrítico-receptivo da apreensão do real de "consciência natural". (C.f. Fenomenologia do Espírito §§76-78). 
Mas esse elemento utópico não pode ser levado a sério demais. Enquanto uma conseqüência ou uma derivação do teor positivo ou prescritivo da razão que discursa sobre as coisas e, no que as critica, oferece-se como melhor que elas, substituindo-as por seu próprio conteúdo, o elemento utópico tende a instaurar uma forma de discurso mais perversa que a que foi evitada quando da crítica da "identidade entre a identidade e a não-identidade". Afinal, se a origem dessa racionalidade utópico-positiva foi o reconhecimento de que o objeto tem uma história, a qual o saber está em posição de negar, o efeito dessa negação deveria ser compreendido enquanto um momento histórico inserido na história do objeto. Ao negar o objeto estático, o saber não aponta para a dissolução desse objeto num magnânimo mar de riqueza de sentido mas, ao contrário, é o saber que assume caráter de coisa estática, em seu esforço por se tornar comensurável com o objeto. Em termos concretos, significa que o saber não pode negar a história exceto enquanto história, trazendo para dentro de si conteúdos específicos da história, de tal modo que, então, qualquer discurso sobre o discurso que tenha por conteúdo a elevação deste ao status de pura utopia, pura novidade, plenitude de sentido, será justamente o mascaramento de uma reacionária intimidade - transformada, deste modo, em corrupção entre o saber e as coisas.

\section{Problema histórico da representação: dialética do esclarecimento}

É assim que duas correntes do pensamento trandicional, a mesquinha primazia do método, e o petulante e despreocupado triunfalismo do discursar, hoje freqüentemente denominadas, nos meios filosóficos, pensamento "analítico" e "continental", se encontram e se beijam no rosto. A abstração da teoria do conhecimento e os esforços de elaboração imediata do real, ou de buscar o ser através da história, resultam na legitimação reforçada do mundo, dos objetos, e do saber, conforme são: a primeira, promovendo a cegueira diante da historicidade, e a segunda obscurecendo a resistência bruta da história, ou reduzindo a história à historicidade. $\mathrm{O}$ pano de fundo desse procedimento é a corrupção do pensamento que quer ou bem resguardar-se das coisas, ou bem impregná-las de sentido, pela forma da lógica de organização da sociedade onde as coisas estão: pelo princípio de troca. Na medida que evoca o princípio de troca como o problema fundamental da ideologia - tanto da ideologia especializada dos filósofos, 
quanto da ideologia espontânea, mas não menos sofisticada, que transita como bem cultural imediatamente desfrutável - a dialética negativa se insere na tradição da Crítica da Economia Política marxista, e aponta para um aspecto do funcionamento concreto da conhecida tese da determinação em última instância pelo econômico.

$\mathrm{O}$ argumento de Adorno é que o procedimento que torna o conceito comensurável com o objeto, caracterizando um pensamento que prima pela identidade, é formalmente idêntico àquele que subsume as coisas sob o princípio abstrato do trabalho, tornando-as comensuráveis umas às outras, intercambiáveis. Trata-se, evidentemente, de uma apropriação da teoria do valor-trabalho de Marx - ou, antes, do seu potencial radicalmente crítico $^{18}$ para efeitos de uma crítica à ideologia. Em Marx, o valor aparece como aquela medida de um trabalho socialmente necessário que é exigido para produzir qualquer objeto útil. Esse trabalho precisa ser quantificado porque o processo capitalista de produção subentende a geração de lucro ou o crescimento do capital investido na produção, e o lucro é possibilitado justamente pela acumulação de uma quantidade de trabalho. $\mathrm{O}$ trabalho acumulado, ou a mais-valia, é a diferença aritmética entre a quantidade de trabalho que o trabalhador assalariado coloca na produção das mercadorias e a quantidade de trabalho que é necessária para permitir a subsistência do trabalhador, quantidade essa que é expressa por seu salário. A produção capitalista deve ser organizada sempre de modo que a quantidade de trabalho expressa pelo salário seja menor que a quantidade de trabalho colocada na produção das mercadorias, de tal modo que o resultado positivo dessa diferença, a sobra de valor ou mais-valia, possa ser acumulada. A possibilidade de que tal resultado seja positivo, ou de que o salário expresse uma quantidade de trabalho menor que a que o indivíduo é capaz de aplicar na sua labuta diária, deve-se ao potencial que o avanço técnico tem de reduzir a quantidade de trabalho necessária para a subsistência: o salário expressa a subsistência, mas o expediente é sempre mais longo do que o trabalho que seria requerido para produzir os bens necessários à subsistência. É assim que, no seio da sociedade burguesa, em meio aos seus

180 presente resumo desse argumento está baseado principalmente na discussão sobre valor, que Marx empreende sobretudo na Parte 3 do Capítulo 1 do Volume 1 d'O Capital, e no parágrafo da Dialética Negativa intitulado "Sobre a Dialética da Identidade" ("Zur Dialektik der Identität"), DN 149-151. 
princípios liberais de equanimidade universal e troca justa entre equivalentes, está enterrado um logro: o salário sempre é capaz de comprar uma quantidade de trabalho maior do que a quantidade de trabalho que ele expressa em termos de valor.

Mas o logro, aí, não é tanto que os salários são injustos porque são baixos demais. O problema é mais profundo, e não pode ser reduzido a uma questão quantitativa: é a própria redução do trabalho, pela administração capitalista, a um princípio abstrato e quantificável que precisa ser questionado. Para começar, essa quantificação não é historicamente separável da necessidade de explorar o trabalho. A igualdade entre o salário que o trabalhador recebe e o trabalho que ele coloca na produção de mercadorias, ou a eliminação da mais-valia, seria a própria impossibilitação da acumulação capitalista, ou do acréscimo de um valor ao valor que foi investido inicialmente na produção. Ademais, a redução de todas as necessidades humanas a mercadorias comensuráveis e intercambiáveis através da quantidade de trabalho que elas corporificam apenas se dá num contexto em que é necessário relativizar essas necessidades à capacidade dos indivíduos de venderem sua força de trabalho numa quantidade ditada pelos rigores da acumulação e as possibilidades da taxa de mais-valia, e não por suas necessidades materiais, que exigiriam uma quantidade muito menor de trabalho.

A forma do logro do trabalho abstrato é, então, que a suposição de uma capacidade universal de equivalência sugere e sustenta o intercâmbio entre incomensuráveis: a vida mesma, quantificada, é trocada por sua representação abstrata em forma de dinheiro, e esse dinheiro, ainda por cima, representa uma quantidade de trabalho - ou expressa uma quantidade de valor - menor do que ele compra, uma vez que a mais-valia é apropriada. E essa forma é homóloga à da substituição do objeto pelo discurso: a sociedade entra no discurso filosófico, que a repete em sua lógica mesma. Mas a forma dessa intoxicação do pensamento pelo ambiente circundante da equivalência social não está limitada, evidentemente, ao pensar filosófico: "a identidade é a forma fundamental da ideologia" (DN 151). A possibilidade do intercâmbio do dissimilar é a raiz formal da ideologia e, portanto, a crítica da ideologia - de uma forma de pensar - desliza para a crítica de um procedimento social total do qual o discurso é uma parte. É, de fato, essa parte mesma, ou o lugar específico do discurso, que está em questão aí: na medida que o trabalho abstrato é abstrato, exige a 
manutenção - através de muitos meios, é claro, inclusive o cassetete e o míssil - de um código ideológico e uma série de convenções simbólicas que o façam funcionar.

A premência desse código é, talvez, uma peculiaridade da sociedade do trabalho abstrato, que tem que separar a satisfação das necessidades da produção dos bens materiais. Se, em formas sociais anteriores, o trigo colhido era comida (inclusive aquele que era confiscado sob a forma de imposto), na sociedade capitalista o trigo é mercadoria dotada de valor, valor esse que não se descobre inspecionando o trigo, provando-o, moendoo, assando-o com fermento e água, etc. $\mathrm{O}$ valor - e o preço - não estão na coisa mesma, que, consigo, só carrega - quando muito - uma utilidade. Não é a toa que precisamos perguntar "quanto é", e que é impossível suprimir do tom de voz de quem faz essa pergunta uma certa hesitação que trai a desconfiança ou a resignação diante da arbitrariedade de uma relação social que é reificada, tratada como um fato da natureza. Evidentemente, o ato mesmo de enunciar o preço, de submeter a coisa a uma lógica de equivalência que violenta tanto a potencialidade que um alimento tem de alimentar, quanto a inelutabilidade da fome - ou de confirmar a separação entre os bens materiais e a satisfação das necessidades - é apenas a manifestação de um complexo sistema de relações que não podem ser desfeitas através de uma reapropriação do discurso. Adorno nos diz com todas as letras que a crítica ao pensamento que prima pela identidade é a crítica da apropriação de mais-valia e da injustiça social. Mas também adverte que o rancor imediato contra a racionalidade burguesa da identidade esconde um elemento regressivo e autoritário: negar sumariamente o princípio de identidade, sem questionar toda a estrutura que o sustenta num nível prático, resultaria, concretamente, em render as relações sociais à apropriação direta e ao privilégio declarado das cliques $^{19}$, que é o resultado de ideologias imediatistas como o fascismo.

De fato, o fenômeno do fascismo funciona como uma chave para a ideologia contemporânea. Um dos elementos do conjunto de conceitos que, na Dialética do Esclarecimento, Adorno e Horkheimer empregam para fazer com que esse fenômeno se torne inteligível evoca um aspecto da

19 DN 150. Essa observação soa como mais um elemento da crítica adorniana avant la letrre ao pensamento da diferença pós-moderno. 
problemática da Dialética Negativa: trata-se da impenetrabilidade do real à razão. Mas, no contexto histórico específico, este problema aparece com uma conotação muito mais concreta, relevante e importante. Pois, aí, o fato de que a "reflexão, [a] significação e, por fim, [a] verdade" foram incapazes de deter os Pogroms "demonstra" a "impotência" da razão (DE 160) ${ }^{20}$. O discurso crítico não se situa desde um ponto de vista isento que se direciona à violência e à crueldade desde fora; é esse ponto de vista mesmo que, em sua incapacidade de evitar a violência, demonstra sua compatibilidade com ela. É curioso observar que a exigência que Adorno e Horkheimer colocam sobre a racionalidade não é que ela tivesse sido capaz de entender os pogroms, mas de que tivesse podido detê-los ${ }^{21}$. A maneira específica de articulação desses dois momentos - a função gnosiológica do discurso e sua função civilizatória - consiste na contribuição específica dos autores para a problematização da forma contemporânea da ideologia através do fascismo.

No mundo onde o fascismo é possível, tanto as vítimas quanto os agressores estão determinados por uma "cegueira" (DE 158) cuja inteligibilidade é buscada apelando-se a uma formulação que é reminiscente da teoria hegeliana da reconciliação: "os adultos, para os quais o brado pelo sangue judeu tornou-se uma segunda natureza, conhecem tão pouco a razão disso quanto os jovens que obedecem seu comando" (DE 160). Está em jogo um estado de consciência inconsciente ou de ideologia sem discurso, sem momento positivo, sem teses. O conceito de segunda natureza ${ }^{22}$ evoca aquilo que é humano e cultural, mas, ao mesmo tempo, tão opaco em seu conteúdo quanto uma pulsão natural, de modo que o anti-semitismo é caracterizado nos termos de sua própria impenetrabilidade à racionalidade. O contrário dessa abordagem seria encontrar uma razão que explicasse o

\footnotetext{
20 As citações da Dialética do Esclarecimento obedecem o mesmo formato que aquelas da Teoria Estética e da Dialética Negativa. A edição utilizada para as citações foi a primeira edição da tradução brasileira (Adorno, T. W. e Horkheimer, M.: Dialética do esclarecimento. Tradução: G. A. de Almeida. Rio de Janeiro: Jorge Zahar, 1985).

21 Trata-se uma evocação do movimento lógico total das Teses Contra Feuerbach de Marx, as quais põem em questão não tanto o conteúdo da filosofia, mas a questão da sua realização. Veja-se, especialmente, a 11a Tese ("Os filósofos se limitaram a interpretar o mundo diferentemente; cabe transformá-lo"). O mesmo tema alimenta a argumentação marxiana na Introdução à Crítica da Filosofia do Direito de Hegel.

22 O qual, no contexto do pensamento marxista, é freqüentemente utilizado para fazer referência ao fetiche da mercadoria - à naturalização do "quanto é", a substituição da relação social por uma relação coisal.
} 
anti-semitismo e, daí, em certa medida, o justificasse, o tornasse intercambiável ou comensurável com sua própria crítica. Mas na medida que os processos sociais são brutais e sem-sentido, a teoria não deveria procurar desfazer-se da brutalidade e da falta de sentido, atribuindo um conteúdo a estes elementos - o que a faria incorrer em forma qualquer de idealismo apologético, ainda que dotado de má-consciência - mas expressar a brutalidade e a falta de sentido, ou fazê-los aparecer, o que, portanto, deve ser empreendido pela teoria e na teoria, ou seja, formalmente. A segunda natureza, a opacidade social, ou a sociedade dessocializada, enquanto momento ou objeto de uma teoria crítica da sociedade, é precisamente aquilo que não pode ser dissolvido na argumentação racional civilizada, porque essa dissolução causaria a perda da especificidade do opaco - ou, o que é pior, a assimilação entre o opaco e o conhecimento, essa indiferença entre o saber e a sua ausência que é o fenômeno cultural contemporâneo. Uma vez que o que está em jogo é a teoria, entretanto, um encontro puro e imediato com a opacidade também é evitado, visto que o mito da imediatidade e a pureza do opaco seriam, assim, traídos por uma espécie de acesso ilimitado ao opaco. A apresentação ou expressão formal é, por isso, uma elaboração. Como diz Adorno em outra parte, um filósofo que, desde o conforto do seu escritório, tenta inventar estruturas estético-conceituais que reproduzam a violência experimentada por aqueles que foram assassinados, está mostrando sua participação no escárnio ante às vítimas do extermínio (DN 354). Atentar ao opaco deve ser dar conta dele de forma opaca, por meio de um discurso que não tente dar uma solução teórica-discursiva para um problema que não é teórico-discursivo. Tal discurso não pode explicar a realidade e livrar-se dela, deixando o próprio relato em seu lugar: embora um discurso seja criado a seu respeito, a realidade não pode perder sua opacidade específica; essa opacidade deve ser complexificada. O mote geral para esse processo de apreensão da realidade é encontrado na Minima Moralia: "O cisco no teu olho é a melhor lente de aumento." 23

Mas seria perverso e malicioso, ou então uma piada de péssimo gosto, defender que o caráter repulsivo da ideologia do anti-semitismo está limitado ou especialmente manifesto nessas suas características intrínsecas enquanto discurso que motivam a resposta teórico-formal. Tais

${ }^{23} \S 29$ (T. W. Adorno: Minima Moralia. Tradução: L. E. Bicca. Rio de Janeiro: Ática, 1993, p. 41). 
características, com o anti-semitismo, extravasam a si próprias: o antisemitismo expressa um momento em que de fato tornou-se possível vivenciar - de forma administrada - as fantasias destrutivas mais horrorosas. Ainda assim, e mesmo no que desempenha um papel social na exterminação dos judeus, a ideologia anti-semita não aponta para nada fora de si mesma - ou seja, nada além de uma finalidade ideológica. Ela está marcada por uma forma peculiar de relação - no caso, falta de relação com uma exigência que se coloca sobre o discurso como um todo: sua funcionalidade no cumprimento de fins práticos ou, em última instância, sua conexão com o impulso de auto-preservação. A pedra de toque deste argumento é o fato de que não havia qualquer vantagem econômica significativa a ser alcançada através do confisco de propriedade dos judeus ${ }^{24}$ - mas mesmo que houvesse, a abordagem funcionalista que a detectasse e oferecesse como explicação não daria conta do esforço para extermínio total dos judeus, que foi, a partir de certo momento, a finalidade estabelecida pelo anti-semitismo na Alemanha Nacional-Socialista ${ }^{25}$. Este programa, de fato, não tem justificação externa para si mesmo. Mesmo que tenha havido algum propósito oculto no populismo ideológico nazista - Ernst Mandel demonstra como o grande capital industrial beneficiou-se enormemente do nacional socialismo ${ }^{26}$, o elemento anti-semita dessa ideologia permanece autocentrado. "A ação torna-se realmente um fim em si e autônomo, ela encobre sua própria falta de finalidade" (DE 160-161).

De maneira a proporcionar a apreensão do anti-semitismo como uma ideologia autocentrada, é necessário identificar o aspecto não-ideológico ou extra-discursivo que, embora não o possa justificar, proporciona-o um espaço social, para início de conversa. Se tal aspecto extra-discursivo não é buscado e encontrado, a teoria sucumbe ao obscurantismo do próprio comportamento ideológico: ela tenta exaurir o objeto que procura descrever

24 "O fato de que a demonstração de sua inutilidade econômica antes aumenta do que modera a força de atração da panacéia racista (völkisch) indica sua verdadeira natureza: ela não auxilia os homens, mas sua ânsia de destruição. (...) 0 anti-semitismo mostrou-se imune ao argumento da falta de rentabilidade. Para o povo, ele é um luxo." DE 159.

${ }^{25}$ Esse é um dos pontos do argumento de Moishe Postone em "The Holocaust and the Trajectory of the Twentieth Century" in M. Postone e E. Santner (eds.): Catastrophe and Meaning. London: University of Chicago Press, 2003

${ }^{26}$ C.f. sua introdução a L. Trotsky: The Struggle Against Fascism. New York: Pathfinder Press, pp. 9-46, 1971. 
em termos da descrição mesma, a qual, neste caso, não iria mais longe que a caracterização da violência em seus próprios termos, visto que o problema que se coloca é justamente o de uma ideologia autocentrada. Uma teoria que se comportasse dessa maneira nesse contexto não mereceria esse nome, e o discurso que a quisesse sustentar teria aspecto e função de coisa: a teoria que, ao desdobrar-se, tentasse apresentar o desdobramento como parte de si mesma, repetiria a lógica da opacidade que caracteriza o tipo de ideologia da qual o anti-semitismo é um exemplo. A auto-centralidade do discurso precisa, portanto, ser vista como traço não só do discurso, mas da história desse discurso. A pergunta pela forma da ideologia cede terreno à pergunta pelo contexto da ideologia, ou pelo papel social do discurso e, mais especificamente, pelo momento histórico em que a habilidade do discurso de alcançar algo fora de si mesmo foi perdida ou chutada para escanteio. Essa habilidade precisa ser entendida não apenas em termos de razões discursivas, mas de constrangimentos externos ao discurso. Não que esses constrangimentos não deixem pistas na estrutura mesma do discurso, que deve estar formalmente organizado segundo as exigências que lhe são feitas desde fora. A forma da ideologia carrega embutida o registro do que a sociedade espera do discurso ideológico, ou do papel que foi relegado ao discurso através de processos que transcendem o discursivo. A disposição da figura discursiva da transcendência é uma dessas pistas formais.

A transcendência, no sentido aqui mobilizado, é aquele elemento formal de acordo com o qual a ideologia sugere uma relação com elementos que estão do lado de fora dela e além do alcance da sociedade onde ela é formulada. Não quer dizer que a transcendência seja, ela mesma, uma figura não-ideológica: evidentemente, a imagem cultural ou o discurso político sobre aquilo que é inviável dentro do espaço imaginário que um período histórico ou um grupo social considera como seu é de importância ideológica crucial. Mas essa importância implica o momento negativo (por mais abstrato que seja) de uma abertura (por mais suspirante e impotente que seja) para algo que aparece como uma alteridade inacessível ao mundo acessível: é a representação do objeto desejado, o reconhecimento da falta, feitos em termos que a tornem palatável. A forma mais ilustrativa da transcendência é aquela que aparece no discurso religioso: relatos cosmológicos como o do catolicismo descrevem um mundo supra-sensível cheio de abundância e beatitude. Essa descrição, evidentemente, só tem sentido na medida que contrasta com uma outra que se aplica a um mundo 
sensível cujas principais características não são a abundância e a beatitude. Esse contraste abre espaço lógico para uma crítica da ideologia que se voltará contra a religião e dirá: muito bem, se o paraíso de abundância e beatitude é bom, por que não exigir que a Terra mesma seja cheia de abundância e beatitude? Este motivo passou com certas alterações para a ideologia protestante, com seu espaço próprio para uma ênfase nas obras e na realização material, a qual serviria, de alguma forma, como um espelho para o bem-estar supra-sensível. A ideologia liberal secular ou agnóstica do Esclarecimento afastou-se ainda mais da abundância supra-sensível, e deu atenção a valores que, em certo sentido, compartilhava com o discurso religioso mais recente, tais como a justiça, a eqüidade e a liberdade pessoal subjetiva, ao mesmo tempo que lhes emprestou um caráter mais históricosocial. A Declaração dos Direitos do Homem de 1789 - com a simbologia meio neoclássica utilizada na sua apresentação gráfica original, o anjo, a resplandecente pirâmide com o olho, a luz apartando as nuvens do céu - é um documento desta ideologia secular que ainda preserva o elemento de transcendência e, portanto, pode ser uma inspiração para o que poderia ser chamado de crítica ideológica imanente: a crítica da ideologia e da realidade que realça a inadequação entre as duas. Aquilo que, outrora, era chamado de política radical de esquerda tinha a ver com esse elemento de crítica: de um lado, a exigência da realização dos valores esclarecidos e, do outro, a crítica da insuficiência desses valores devido ao seu desempenho precário na realidade social. O ponto de partida é enxergar tudo aquilo que, tendo lugar na coleção sócio-cultural de representações, é adiado por essas mesmas representações, ou por elas isolado no reino do supra-sensível religioso ou ideal, como passível de se tornar um guia para a ação concreta no mundo sensível.

O problema histórico que isso implica, entretanto, é que a crítica ideológica de esquerda, no jogo transcendência-imanência, tende a manterse amarrada às bases do idealismo humanista burguês. Assim, o empreendedorismo idealista da realização progressiva das idéias transcendentes fica limitado concretamente pelas condições da expansão capitalista como um todo. E essas condições são, concretamente, bastante específicas: o sujeito autônomo que é o sujeito de um processo de acumulação privado de trabalho alheio está limitado pela passagem - ditada pela inexorável tendência à concentração de capital - do momento liberal para o momento monopolista do capitalismo; a noção de liberdade abstrata, 
no fim das contas, só se realizou como capacidade a priori de vender a força de trabalho num mercado que nem sempre precisa dela; a apropriação dos frutos do trabalho e melhor distribuição das benesses da produção social está condicionada pelas exigências da acumulação de mais-valia e da separação absoluta - decorrente da mera distinção fundamental entre valor de uso e valor de trocas - entre a satisfação das necessidades e a necessidade de gerar lucro. Significa, mais especificamente, que a crítica imanente não acontece apenas como fenômeno de negação da sociedade burguesa, mas como um processo interno: a filosofia hegeliana da história e do direito dá testemunha disso, através do conceito de uma razão objetiva que, superando aquela razão (kantiana) que se dirigia desde o sujeito para o mundo com preocupações práticas, tem já, ela mesma, existência e conseqüências práticas, num processo de interação material entre o Estado e a sociedade civil. A palpável utopia laica burguesa não é inteiramente externa aos métodos da sociedade burguesa, e tampouco deixa de estar limitada por eles. Os limites dessa utopia, os limites do jogo crítico mesmo entre imanência e transcendência - a positividade dessa última entendida na negação da primeira, positividade essa que só é possível nos termos simbólicos socialmente disponíveis, ou seja, imanentes - estão atrelados à capacidade de inclusão social do próprio capitalismo, esse sistema de reprodução que está determinado em seu âmago pela expropriação, o logro da troca universal, e o privilégio social.

Não quer dizer que a expansão do capitalismo é desde sempre, em sua manifestação de discurso ideológico modernizador e inclusivista, estritamente auto-referenciada. O capitalismo não é um discurso; os objetos de sua ideologia não são objetos ideológicos: são coisas. A expansão capitalista traz acesso a bens materiais cuja utilidade está além do papel que desempenham na acumulação de capital, de tal modo que, se o acesso a esses bens cai necessariamente aquém do universo social total, isso pode, inclusive, ser traduzido em termos ideológicos - por exemplo, através do eterno progressismo sul-americano de superação do atraso, ou pelas chamadas políticas de inclusão. Essa tradução, assim, tem o caráter de promessa, e a realização dessa promessa, por mais fantástica que seja, subentenderá - a princípio, ou formalmente - um encontro entre (mentirosas) estratégias administrativas e o real onde a água vai chegar ou não no sertão, a saúde pública será salva ou não, a recessão inevitável será evitada ou não. A transcendência, neste sentido, figura como benesses 
capitalistas internas ao capitalismo - mais mercadorias, mais serviços, mais salários, qualquer emprego melhor do que nenhum, etc. - mas externas ao discurso mesmo, uma vez que está em questão a satisfação de necessidades reais $^{27}$ - muitas vezes, as mais básicas, como água e comida -, algumas das quais são, aliás, indiferentes ao capitalismo, ainda que ele as reconheça, incorpore e relativise. Nesse sentido específico, a transcendência é sugerida pela produção capitalista de bens de consumo úteis, a qual, em seus estágios iniciais, aponta para um movimento de modernização, de expansão, de incorporação cada vez maior da humanidade na produção capitalista e participação nos produtos dessa produção; ao mesmo tempo, uma vez que os mercados se vão saturando, e a mão de obra passa a ser cada vez mais desnecessária dado o desenvolvimento técnico, essa inclusão se vai tornando cada vez mais uma ideologia transcendente mentirosa. Mas quando essa transcendência se torna o clamor não pela satisfação de necessidades, mas pela participação no capital, reprimindo-se o momento da diferença entre produção capitalista e bens materiais necessários à subsistência, revela-se a tendência à identificação entre transcendência e imanência que está subentendida logicamente pela própria forma da ideologia burguesa. O caráter a priori da entidade lógica da subjetividade burguesa, que figura concretamente no discurso capitalista modernizante como uma força de transformação e expansão, é independente da idéia daquilo que será transformado e do teor dessa expansão: Marx mesmo já havia detectado que o capitalismo é um sujeito automático ${ }^{28}$, um processo de reprodução de si próprio. E uma vez economicamente amadurecido - ou seja, uma vez que tenha encontrado limites físicos para sua expansão - a transcendência capitalista muda de conteúdo: as capacidades do capitalismo de empreender aquilo que perversamente se chama de "inclusão social" são gradativamente prejudicadas pela redução tendencial do emprego de força de trabalho; os avanços da técnica que passa a projetar a natureza como algo sempre cada vez mais abarcável pelos conceitos de sua própria manipulação

\footnotetext{
${ }^{27}$ Ao menos parcialmente. Marx observa por diversas vezes como a mercadoria, que é produzida para ser trocada, só pode ter um valor de troca se tiver um valor de uso, por mais que a necessidade à qual esse valor de uso está atrelada seja uma necessidade criada ou destrutiva. 0 que não quer dizer que, a depender apenas das exigências abstratas da acumulação, mercadorias completamente inúteis não seriam postas em circulação, se pudessem ser vendidas.

${ }^{28}$ As formas econômicas de ficcionalização de capital, que assumem maior importância nos níveis mais tardios da acumulação total, manifestam concretamente esse conceito.
} 
tornam o mundo cada vez mais indistinto do próprio capitalismo; a maturidade institucional dos mercados internacionais tornam os investimentos cada vez mais móveis - ou seja, cada vez mais independentes daquilo que acaba se configurando como as meras convenções da geografia, e mais capazes de atender suas próprias pulsões internas de autoacumulação.

Enquanto essa maturidade onipresente do capital está ligada a uma expansão interna onipotente, como no boom econômico do pós-guerra, a degradante metamorfose das oposições de esquerda em partes constituintes da situação, através da adoção da ideologia do Estado de Bem-Estar, pode ainda estar ligada à satisfação ampliada das necessidades materiais. No entanto, quando a expansão interna atinge seus limites, o discurso oficial revela-se o de uma apologia irrestrita às necessidades do próprio sistema, de tal modo que o brado por empregos se transforma na consoladora asserção de que qualquer emprego é melhor do que nenhum, e a precarização do trabalho agora permanente é oferecida como paradigma inspirador para o novo empreendedorismo proletário: "Você S. A.". O inclusivismo capitalista só cola para o que antigamente se chamava de classes médias, lutando, com um diploma na mão, por vagas nas fileiras da administração da vitimização do resto da sociedade pelo capital. As possibilidades reais do sistema econômico, regido pela especulação financeira, de satisfazer mesmo as necessidades de subsistência mais básicas vão por terra: ao contrário, como demonstram as bolhas imobiliárias que, nos primeiros meses depois de estouradas, contabilizaram mais de um milhão de processos de despejo nos Estados Unidos ${ }^{29}$, essas necessidades aparecem como uma função daquela especulação; a absurda dissociação entre as técnicas produtivas que poderiam alimentar todos os habitantes do planeta $^{30}$ e a galopante e persistente ampliação da fome e da miséria no mundo; uma multiplicidade repetitiva de fenômenos do mesmo fazem aparecer o caráter autocentrado e acidental da produção material contemporânea.

\footnotetext{
${ }^{29}$ Folha Online: "Despejos nos EUA são problema urgente e pedem soluções inovadoras, diz Fed". In Folha Online, 07/05/2008. http://www1.folha.uol.com.br/folha/dinheiro/ult91u399439.shtml. Acessado em 10/08/2008.

30 FAO: "Reducing poverty and hunger: The critical role of financing for food, agriculture and rural development." 2002. http://www.fao.org/docrep/003/Y6265e/y6265e00.htm. Acessado em 10/08/2008.
} 
A forma total da proposição ideológica fundamental do antisemitismo é homóloga a essa que o capitalismo assume a partir do momento histórico de sua maturidade, e cuja autocentralidade não oferece qualquer ponto de partida transcendente para a crítica imanente, sepultando a figura do intelectual progressista de esquerda. Não quer dizer que não haja, nessas ideologias, um momento de falsidade: a alegação de que a Alemanha ariana seria salva pelo extermínio dos judeus é, evidentemente, uma mentira. Contudo, não só o objetivo negativo e destrutivo desse discurso mentiroso está esvaziado de qualquer conteúdo específico passível de ser questionado com base na falta de proveito concreto do resultado da realização suas promessas, mas, além disso, o resultado total do extermínio também não poderia, em si mesmo, ser abordado em quaisquer termos outros que ele mesmo, uma vez que o elemento real, palpável, utilitário, está ausente desse discurso que, na destruição real do inimigo fantástico, realiza sua adequatio prático-conceitual. Havia, é claro, o mito da raça superior; mas não havia nada que pudesse dotar esse mito de um conteúdo concreto para além do extermínio daquilo que era o outro que a raça ariana, e está subentendido nesse mito, e é representável apenas através de alguma variação dele.

A situação ideológica corresponde a um momento histórico no qual "a religião foi integrada como patrimônio cultural, mas não abolida. A aliança entre o esclarecimento e a dominação impediu que sua parte de verdade tivesse acesso à consciência e conservou suas formas reificadas" (DE 164-165). Quer dizer que aqueles elementos, na religião, que dirigiamse ao mundo - seu "momento de verdade" - foram suprimidos, pois aquelas imagens mesmas da esperança, da abundância, da beatitude, que a religião projetava foram comprometidas, uma vez que o ponto de vista racional - o "princípio de realidade" - que seria capaz de converter esses valores transcendentes e suprassensíveis em objetivos concretos e palpáveis aliouse, ele mesmo, com a violência, ou a "dominação." A ausência da representação de um elemento de vantagem material causa uma identidade entre os meios e os fins. Essa identidade é tal que a esfera onde a representação ideológica dos fins tem lugar é ocupada com um discurso sem qualquer referência externa ou elemento auto-limitador. O extermínio dos judeus é manifestação dessa autocentralidade em seu aspecto negador. Neste contexto, o engajamento psicológico-espiritual, a fé, é privada de conteúdo transcendental, e se exaure na aparência, no domínio da imanência total. O poder autocentrado, imanente a si mesmo, é, da mesma forma, 
poder exibido ou poder como aparência. Sua manifestação é a força bruta, a violência explícita que intimida. As paradas civis e militares que marcavam a vida cultural sob o Nacional-Socialismo complementam o exercício da violência real: o Estado que fala através delas se esgota, enquanto aparência, na apresentação dos tanques, das roupas folclóricas, da disciplina formal, dos uniformes ameaçadores, ao invés de esconder-se por trás destes elementos - ao contrário, por exemplo, do que acontece numa procissão religiosa, em que os fiéis se colocam diante de instâncias que transcendem aquilo que está sendo representado através das imagens e cânticos. A ideologia não esconde, e não explora a inadequação: ela dirige-se à realidade, e empresta credibilidade a ela simplesmente em sua afirmação adequada.

A tese central da Dialética do Esclarecimento - a de que, historicamente, concretizou-se uma identificação entre a racionalidade e a dominação (DE 11-12) - aparece, assim, nos termos da discussão do antisemitismo. O pano de fundo histórico deste aparecimento é o surgimento do Nacional Socialismo no seio da República de Weimar, como uma resposta ao fracasso do partido social-democrata de realizar sua promessa de uma sociedade viável em face do colapso econômico, mas sem alterar fundamental as relações econômica de produção. A imanência representacional da ideologia nazista é coetânea a essa peculiar situação marcada, também no âmbito econômico, por um comportamento formalmente autocentrado. É preciso perceber a concretude histórica que a tese da ideologia autocentrada adquire aí. A tal forma ideológica absolutamente imanente não desempenha o papel de justificação da realidade, mas de um mecanismo de visibilidade para a mesma. Entretanto, o aspecto autocentrado dessa visibilidade se relaciona com o que está do lado de fora dele segundo uma forma obscurantista. A ideologia nazista não deixou de funcionar como uma ferramenta para o benefício imenso de interesse de classe sob o Nacional-Socialismo. Os procedimentos econômicos desencadeados na Alemanha nazista permitiram a arrancada de um capitalismo nacional cujo desenvolvimento havia sido interrompido depois da derrota na competição imperialista da Primeira Guerra Mundial. Ernest Mandel apresenta alguns números que confirmam o crescimento econômico que foi alcançado através da concentração de poder executivo num estado autoritário com extensivo apoio popular. Os lucros industriais nacionais não-distribuídos, entre 1932 e 1938, aumentaram de 17,4\% a 
$26,6 \%$ do produto nacional, e o capital total das corporações alemãs subiu de 20,6 bilhões de Reichmarks em 1932 para 29,6 bilhões de Reichmarks em 1938, enquanto que, no mesmo período o número de corporações diminui de cerca de 10.000 para cerca de $5.000^{31}$. É claro que promover esses aumentos na acumulação e concentração do capital exigira esforços específicos por parte do maquinário estatal, entre eles a formação compulsória de cartéis, "mergers" sob a direção dos "Líderes para Defesa da Economia", que favoreceram a concentração de capital, e a destruição das organizações operárias, de modo que é evidente que um nível de ação com respeito a fins práticos e palpáveis seguiu existindo. Mas não é isso que está em questão na tese da ideologia autocentrada. O que os procedimentos político-econômicos empregados pelo Estado Nacional-Socialista viabilizam, num movimento que Moishe Postone caracteriza como a revolução burguesa atrasada da Alemanha $^{32}$, é a continuação de um capitalismo que já se distanciou inteiramente da tensão entre a satisfação das necessidades materiais e a perpetuação das relações de produção: aquelas foram abarcadas por essas. O Estado e a sociedade se tornam meras variáveis na função da acumulação capitalista em sua maturidade.

\section{Capitalismo tardio e o esquema da cultura de massas}

Adorno não deixou de expressar numerosas vezes, ao longo de sua obra, o problema econômico fundamental que está implicado aqui, embora tais expressões não estejam entre o repertório de citações preferido dos comentadores. Esse problema é uma revisitação à tradicional condenação marxista da contradição entre as forças produtivas e as relações de produção: a idéia de que a habilidade técnica objetivamente existente de produzir bens materiais para satisfação das necessidades choca-se com as relações de produção que regulam a produção e distribuem os bens de acordo com os interesses daqueles que têm o poder sobre os instrumentos da produção $^{33}$. A contribuição adorniana à problematização dessa contradição,

\footnotetext{
${ }^{31}$ L. Trotsky: The Struggle Against Fascism. Introdução, pp. 30-31.

32 "The Holocaust and the Trajectory of the Twentieth Century" in Catastrophe and Meaning.

${ }_{33}$ A presente apresentação da posição adorniana está baseada no texto "Capitalismo tardio ou sociedade industrial?" ("Spätkapitalismus oder Industriegesellschaft?" in T. Adorno: Gesammelte Schriften 8 (Soziologische Schriften I), pp. 354-369).
} 
em termos lógicos, está inserida numa tradição de intelectuais que tentaram pensar o porquê da revolução proletária não ter resultado do desenvolvimento excessivo dos meios técnicos, e seu conteúdo específico é a explicitação do que acontece quando a contradição é historicamente congelada, e o acúmulo de meios produtivos convive com um desenvolvimento das estruturas de repressão e controle. O congelamento da contradição acontece nesse mundo onde o lampejo que detonaria a contradição, o movimento de massas, é paralisado pela ausência de consciência de classes (a qual "não é produzida imediatamente pelo ser social"34), ausência essa que Adorno relaciona com a diminuição do empobrecimento do proletariado e sua inserção progressiva dentro do mundo burguês ${ }^{35}$. Ao mesmo tempo, "o processo econômico continua a perpetuar o domínio sobre os seres humanos": Adorno não confunde a ausência da consciência com a ausência daquilo que deveria ser seu conteúdo, e tampouco considera que a constituição das classes mesmas depende de seu momento de organização política, insistindo que está dada "a mesma opressão de antes, que, hoje, se tornou anônima"36. Essa opressão é determinada pelas relações de produção capitalistas $^{37}$, ainda que 0 desenvolvimento das forças produtivas tenha sido tal que quase justifique a indagação de se ainda se trata do mesmo sistema que se instaurou com a Revolução Industrial: a interferência do trabalho humano no processo produtivo se tornou periférica, mas o que é mais significativo é que "é inegável que o aumento da satisfação das necessidades materiais, a despeito da sua distorção pelo aparato, sugere de maneira incomparavelmente mais concreta a possibilidade da vida sem necessidade. Mesmo nos países mais

\footnotetext{
34 Ibidem p. 358.

35 O texto foi escrito em 1968, e esse traço social aparece dentro do contexto do boom econômico do pós-guerra, que duraria ainda um par de anos. 0 empobrecimento do proletariado, entretanto, tampouco levou, através do messiânico determinismo histórico, à consciência de classe revolucionária. As grandes massas ostracizadas do processo produtivo, cada vez mais dispensáveis desde o ponto de vista da acumulação de capital ficcionalizada, não se politizaram: criminarizaram-se. A resposta a isso, por parte da esquerda realmente existente, tem sido insistir com sanha alucinada num discurso do trabalho ao qual, naturalmente, a vasta massa de desempregados e precarizados, que não são mais reserva de nada, é tão indiferente quanto o capital.

${ }^{36}$ Ibidem, p. 360.

${ }^{37}$ Ibidem, p. 361.
} 


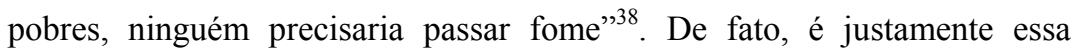
possibilidade tão gritante de abolir a necessidade que faz com que sua satisfação seja distorcida. O que se dá é que "as forças produtivas são, mais do que nunca, mediadas pelas relações de produção, talvez tão completamente que essas vêm a aparecer como a essência daquelas, que se transformam completamente numa segunda natureza. (...) A necessidade que tende a reduzir-se à aparência infecta os bens com seu caráter de aparência." 39

O mundo onde as relações de produção não foram negadas pelas forças produtivas, onde a revolução burguesa tardia alemã interfere no movimento de massas e no processo de concentração de capital, onde a militarização da sociedade cria esquemas de revitalização econômica ${ }^{40}$, é o mundo no qual a ideologia em geral perde a capacidade de descrever objetivos transcendentes, fictícios ou não, na medida que os objetivos concretos e palpáveis - a satisfação universal das necessidades - poderia ser alcançada, e não é. A ideologia, portanto, está presa à imanência. É justamente a habilidade de configurar esperanças para além da realidade concreta - em contraste a outras, formuláveis, por um espaço dentro dela que é prejudicada, na medida que a satisfação é detida de maneira arbitrária e contingente, e não por impossibilidade: se os modos mais primitivos de ideologia eram marcados por uma consolação oferecida pela imagem do logicamente possível, tal imagem, sob o capitalismo tardio, não é mais um refúgio à realidade, mas o escárnio da irracionalidade do estado persistente de insatisfação. A produção de representações recua ante à descrição da realidade que não veio a ser, e à projeção de um futuro que poderia ser. Ela

\footnotetext{
38 Ibidem, p. 362. A centralidade do problema da satisfação das necessidades materiais também é expressa por Adorno em uma passagem não muito citada da Minima Moralia (cit. §100, p. 137). "Quando se pergunta pelo objetivo da sociedade emancipada, obtêm-se respostas tais como a realização das possibilidades humanas ou a riqueza da vida. Tão ilegítima é essa questão inevitável, tão inevitável é o caráter repelente, impositivo, da resposta, que traz à lembrança o ideal social-democrata de personalidade, próprio daqueles naturalistas barbaças do século XIX, desejosos de gozar a vida. A única resposta delicada seria a mais grosseira: que ninguém mais passe fome. Tudo o mais estabelece, para uma situação a ser determinada segundo necessidades humanas, um comportamento humano formado a partir do modelo da produção como um fim em si mesma."

39 "Capitalismo Tardio ou Sociedade Industrial", p. 365.

40 "As relações de produção dificilmente poderiam se perpetuar, evitando, ao mesmo tempo, o choque apocalíptico das crises econômicas, se uma parcela excessivamente grande do produto social - para a qual, de outra forma, não há mercado - não estivesse dedicada à produção dos meios de destruição." Ibidem, p. 366.
} 
se volta para o que existe, e o apresenta como aparência, como o desejável; mas esse desejável não tem elemento transcendente: ele é aquilo que está dado. Reciprocamente, o que está dado, o que coexiste com a possibilidade da satisfação total, e a substitui com uma arbitrária parcialidade, se desmancha nos comentários estetizantes que devem fazer com que o que está dado seja mais do que o meramente dado e apareça como o desejado. "O real se torna sua própria ideologia"41.

Essa forma de ideologia, a qual só pode ser descrita adequadamente em termos que parecem se situar nas margens da sintaxe de qualquer idioma, se oferece ao indivíduo como parte de sua sujeição à ordem socioeconômica vigente que, a ferro e fogo, sobrevive a si mesma. Sua função social não é exercida através de mecanismos que promovem a ocultação do estado de coisas, mas sim sua visibilidade, e isso evidentemente só é possível quando a neutralização política da ideologia não se deu apenas em níveis cognitivos, com a extinção da crítica imanente e sua substituição pela desesperada vontade de fazer parte, mas também através de métodos de controle material efetivo. A ideologia justificativa é um traço de sistemas sociais onde as relações de classe dependem de uma tensão e de um equilíbrio de forças; a ausência dessa forma ideológica marca sociedades "onde predominam puras relações de poder",42, e onde toda crença, portanto, é cínica, e motivada pelo desespero ${ }^{43}$. Se a estrutura mesma da crença, da convicção moral, é substituída pela imperiosa necessidade de adesão, resultado afirmativo da coação de um universo social que aparece para o indivíduo como indiferente às suas necessidades e capaz de destruí-lo através de uma superabundância de meios - campos de extermínio, bombas atômicas, forças especiais de polícia, desmazelo simples e brutal - a vida adulta em sociedade implica - contraditoriamente? - uma forma de regressão, e isso se aplica tanto à unanimidade assustadora

\footnotetext{
${ }^{41}$ Essa formulação aparece em pelo menos dois textos: "O esquema da cultura de massas" (T. Adorno: "The schema of mass culture" in The Culture Industry: Seclected Essays on Mass Culture. J. Bernstein (ed.). London: Routledge, 1991. p. 55) e no ensaio sobre ideologia dos Excursos Sociológicos (Frankfurt Institute for Social Research: Aspects of Sociology. J. Viertel (tr.). Heinemann: London, 1973. p. 202).

42 Ibidem, p. 190.

43 "Sob pena de uma rápida ruína, os membros de cada camada social devem engolir sua dose de orientações. Eles têm que se orientar tanto no sentido de se informarem sobre os modelos de aviões mais recentes quanto no sentido da adesão a uma das instâncias dadas do poder." DE 187.
} 
do Terceiro Reich desfilando pelas ruas, quanto à troca de votos por água que ocorre nos sertões de todas as democracias ocidentais ${ }^{44}$.

Para ser entendido adequadamente, de fato, o problema deve ser retirado das altas esferas dos sistemas políticos manifestos - onde o bomsenso a priori levanta a objeção de que não dá para comparar a democracia ocidental com o fascismo, e a ciência política apologética se retrai diante de tamanha falta de rigor -, e arrastado para os baixios estruturais da produção material: a ideologia absolutamente imanente na qual ninguém acredita em sentido enfático, mas a que se submete com o sorriso e o franzir do cenho esperados, é a conseqüência direta da configuração das forças produtivas em sua relação com as relações de produção, configuração essa da qual emana a negação patologicamente insistente da determinação pelo econômico e da atenção sobre a produção material.

No capitalismo tardio, a produção material se apresenta objetivamente como a "modernidade congelada"45 em que a história foi desativada e o único sujeito é o capital. A produção superabundante que não satisfaz necessidades, ou só o faz de modo contingente, aparece ela mesmo como o resultado autocentrado de um processo que é seu próprio sujeito e objeto, ou seja, a produção mesma é autocentrada. O momento do consumo da produção, assim, é, ele mesmo, um momento da produção ${ }^{46}$, já que seu sentido específico - a satisfação da necessidade - não tem lugar objetivo. Mas a produção só pode se apropriar do consumo através da elaboração desse último em termos representacionais: o Capital, sujeito automático

\footnotetext{
44 "Na medida em que a grande indústria não cessa de subtrair à decisão moral sua base econômica, eliminando o sujeito econômico independente (...) a consciência moral perde seu objetivo, pois a responsabilidade do indivíduo por si mesmo e pelos seus é substituída muito simplesmente por sua contribuição ao aparelho". DE 185.

45 "The schema of mass culture" ("O esquema da cultura de massas"), p. 67. As citações desse texto foram feitas traduzindo-se o original alemão ("Das Schema der Massenkultur" in Theodor W. Adorno: Gesammelte Schriften 3. Frankfurt am Main: Suhrkamp Verlag, 1986) com base no texto em inglês, com respeito ao qual algumas divergências foram encontradas.

46 Uns apologetas da cultura de massas no Brasil dos anos 50, citados por Schwarz em um interessantíssimo ensaio sobre o tema, expressaram isso com todas as palavras: "produção e consumo (artísticos) são fases de um mesmo processo, comércio de significados (como tomates, feijão, televisores, sabão em pó, mobília, etc.)" - "Participação da massa (...) é a unificação dos dois estágios do processo: você acaba não sabendo quando acaba a produção e começa o consumo; é tudo uma coisa só - produzir consumindo, consumir produzindo." J. Medaglia: "Suplemento Literário", O Estado de São Paulo, 24 de Abril de 1957. Apud: "Nota sobre vanguarda e conformismo" in R. Schwarz: O pai de família e outros estudos. Rio de Janeiro: Paz e Terra, 1978, pp. 44 e 47.
} 
absoluto, não pode comer os hambúrgueres, destroçar as embalagens plásticas e colecionar as eletrobugigangas, mas tem que produzir todas essas coisas de tal maneira que o consumo delas não seja a satisfação de uma necessidade material daquele que a consome, o que, negativamente, significa que tudo é um luxo e, como tal, leva a marca do supérfluo, do excedente, do que está absolutamente além das necessidades e é incomensurável com elas, em uma palavra: da cultura, ou do que outrora era designado pelo seu conceito enfático ${ }^{47}$. As propagandas de achocolatado e refrigerante que exibem copos e garrafas de onde o líquido sai jorrando e transbordando para todos os lados, numa glorificação gráfica do desperdício, são a manifestação imediatamente visível disso, mas também fazem aparecer o princípio funcional básico do esquema cultural do qual a propaganda é parte tão fundamental. Para os que permanecem famintos, a imagem do excedente - o contínuo desperdício que é parte constituinte das relações de produção - é a expressão adequada da sua posição periférica que ganha, entretanto, os comentários coloridos e fulgurantes de uma violência que é tão mais esmagadora quanto mais oferece, ao mesmo tempo, os parâmetros do desejável, como nos filmes de terror em que o assassino sanguinário é um brinquedo fantasmagórico, um palhaço enlouquecido ou uma criancinha loura de olhar fixo. Para os que estão integrados como objetos do mecanismo automático do consumo, o excedente aparece ele mesmo como imagem: cada coisa que se consome é muito mais do que aquilo que é realmente consumido, é todo um sistema de referências comerciais-espirituais que emprestam o significado que, enquanto meio de satisfação das necessidades, a coisa não pode ter. Por trás das duas posições, está a visibilidade absoluta - a mesma que é proporcionada pela composição entre a última palavra em maquiagem e a objetividade das câmeras quando filmam a atriz impecavelmente maquiada, o "ornamento desornamentado" 48 - do caráter autocentrado da produção.

A esfera dos produtos culturais que não estão ligados diretamente com a propaganda, e que, no linguajar das revistas de fim-de-semana, cairia sob a designação de cultura em sentido estrito - para além da "comida", a

\footnotetext{
${ }^{47}$ É verdade que a noção de cultura enquanto aquilo que contrasta com o reino da necessidade (que, assim, é sobretudo bruta, corporal, animal, material) é uma noção burguesa - talvez seja a mais burguesa das noções. Por isso, o emprego do termo não tem se não uma função histórico-negativa. 48 "O esquema da cultura de massas", p.67. No alemão: "ungeschminkte Schminke."
} 
“diversão, balé” - com seu caráter intrínseco de celebração da emancipação frente às necessidades, é degradada à "aparência (...) da divisão entre diferentes departamentos da produção" ${ }^{\text {"49 }}$. Esses produtos tornam-se parte do esquema do fetichismo da mercadoria, a uma vez disponíveis imediatamente e acessíveis apenas como uma completa alteridade: a cultura não é íntima aos indivíduos nem penetra neles (DE 184) ${ }^{50}$. O mesmo problema do usufruto que determina a fantasiosa experiência do consumo dos demais produtos se coloca na esfera da cultura: cada produto tem que ser mais do que é sem deixar de ser o que é, e o mecanismo que intervém para possibilitar essa reconciliação com a irreconciliação é a informação. As mercadorias culturais devem ser dispensadas dentro de um contexto de permanente comentário e ciceroneamento. Uma vez que, no conceito de bem cultural, está embutida uma imagem de mútua exclusão entre o trabalho e a cultura - a reificação da imagem da superação da contradição entre forças produtivas e relações de produção -, a apresentação dos bens culturais não pode incluir a exibição de sua produção, e fica, então, confinada ao produto final, à mera re-aparência do bem cultural: todo elemento de significado transcendente é eliminado, e a mediação é esgotada na mediação do produto por um produto ${ }^{51}$. "A cultura de massas é um sistema de signos que assinalam a si mesmos" $"$. Não há realmente qualquer diferença entre a natureza da informação e a natureza daquilo sobre o que ela informa: essa diferença se esgota na culturalização das meras coisas e na coisificação dos discursos. A forma da instituição da informação cultural, assim, transborda a si mesma, e todo consumo assume a forma de consumo cultural.

Mas o que está em jogo aqui é muito mais do que uma lamentação sobre o jeito como as coisas estão e para onde esse mundo vai. O momento em que propaganda se torna informação, e o interesse do vendedor é

\footnotetext{
49 Ibidem, p. 55.

50 Isso é verdade tanto para a participação universal no privilégio, que era o teor do mito da raça ariana sob o Nacional-Socialismo, quanto para o acesso às últimas fofocas na revista de personalidades ou para as orientações exclusivas, no guia de variedades, sobre aquele restaurante especial para ter aquele jantar íntimo (c.f. "O esquema da cultura de massas", p. 72).

51 O momento do obscurecimento das relações de produção, o qual será retomado abaixo, é parte crucial da discussão, como bem observa Schwarz: "A reciprocidade da fórmula final - produzir consumindo e consumir produzindo - escamoteia a mediação do capital, que consiste precisamente em separar produção e consumo." O Pai de Família, p. 47.

52 "O esquema da cultura de massas", p. 71.
} 
veiculado objetivamente ${ }^{53}$, é o momento em que "não há mais entre o que escolher", ou seja, o momento em que "a totalidade força aqueles que querem sobreviver a participar conscientemente do processo" ${ }^{\text {. }}$. A visibilidade digerida é, a um só turno, uma espécie de chantagem e logro. Seu teor é a ameaça. De forma que não se trata de uma "suposta estultificação das massas que é promovida por seus inimigos e lamentada por seus amigos filantrópicos". Antes, "as pessoas aprovam a cultura de massas porque elas sabem ou suspeitam que é através dela que lhes serão ensinadas as senhas e comportamentos que seguramente serão necessários como passaporte para a vida monopolizada" ${ }^{\text {} 5}$. Ao contrário de estarem iludidas, "as massas tiram a conclusão correta de sua completa impotência social frente ao monopólio que representa hoje sua desgraça" ${ }^{\text {"56. Quando os }}$ filmes são recomendados com base na relação entre os milhões de dólares investidos e os milhões de dólares arrecadados com a bilheteria, a indústria chama atenção sobre o seu poder e cobra da sociedade sua submissão, sendo que não é mero detalhe que, quando a obtém, isso objetivamente se deve não apenas aos peitos enormes da coadjuvante, mas também aos os gastos astronômicos com a chamada tecnologia de defesa que estão ocorrendo em paralelo, e são registrados nos mesmos termos. Assaltado pela coação explícita da aparência, e refugiando-se na aparência da submissão automática, o indivíduo participa em maior ou menor grau no cinismo que produz a aparência desde cima $^{57}$, de tal modo que "o fíctício, aquilo que hoje deforma toda a satisfação das necessidades, é sem dúvida percebido de maneira inconsciente em sua verdade" ${ }^{, 58}$.

Mas entre a degeneração universal da verdade e o (ausente) reconhecimento da especificidade do falso há uma diferença, na qual reside o caráter de logro da visibilidade violenta promovida pelo esquema da cultura de massas. Para se fazer absoluta, a visibilidade tem, ao mesmo

\footnotetext{
53 "A indústria dos sonhos não fabrica os sonhos dos clientes, mas introduz entre eles os sonhos dos fornecedores." Ibidem p. 80.

54 Ibidem, p. 73.

55 Ibidem, p. 80.

${ }^{56} \mathrm{Ibidem}$.

${ }^{57} \mathrm{~A}$ ideologia contemporânea é "um mero dispositivo de manipulação, um instrumento de poder, no qual ninguém, nem mesmo aqueles que o empregam, realmente acredita, ou espera que seja levado a sério." Aspects of Sociology, p. 190.

58 "Capitalismo Tardio ou Sociedade Industrial?", p. 366.
} 
tempo, que ser parcial, e essa parcialidade marca formalmente os produtos culturais, que repetem meticulosamente os conteúdos sociais. No real que é ideologia de si mesmo, a cultura comporta-se de maneira "auto-reflexiva" O primado da imanência, a continuidade sem conflitos entre o produto cultural e a realidade - a qual tem sua forma mais límpida no realismo das novelas que tratam de assuntos quotidianos, mas que também é capaz de se fazer sentir em temas fantásticos, na ficção científica tão povoada de motivos absolutamente familiares, etc. - consiste na re-instauração dos conteúdos da vida social num lugar estético, ainda que desde sempre já o fossem. Nesse sentido, o filme de aventura representa, através do herói, a versão atualizada do empreendedor burguês sob o capitalismo tardio: uma figura que atravessa torturas mais ou menos horríveis e, quando conquista algo, é confrontada com o fim do filme, de tal modo que o momento do usufruto nunca tem lugar, e a desventura e sua superação acabam afirmando-se como fins em si mesmas. O mesmo motivo formal descreve o objeto da representação estética e a subjetividade extra-estética, baluarte para a orientação na experiência quotidiana. E o fato de que é assim não é acidental: só uma tal circularidade formal é compatível com a sociedade onde a satisfação das necessidades é substituída pela invenção das satisfações, o que, no fundo, se traduz em termos das relações e dos meios de produção, os quais permaneceriam ocultos mesmo se o objeto da formafilme fosse o mau-caratismo dos capitalistas: neste caso, "sua monstruosidade ainda seria sancionada como uma qualidade de indivíduos humanos, o que tende a obscurecer a monstruosidade do sistema para o qual se trabalha servilmente" ${ }^{\prime 60}$. A subjetividade a priori, a personalidade com traços determinados pelo roteirista que se encaixa perfeitamente com o destino determinado pelo roteirista, essa unidade mínima da produção cinematográfica e da literatura realista, é a condensação individualizada da forma difusa do capitalismo tardio: a identidade entre a identidade e a alteridade, entre o repouso e o movimento, o consumo e a produção. Essa decadência da forma sujeito é uma conseqüência da dialética interna da ideologia burguesa: a forma do empreendedor, que levava para o mundo a sua vontade de vencer - para a qual, não obstante, ainda hoje não falta lugar

\footnotetext{
59 "O esquema da cultura de massas", p. 56.

60 Ibidem, p. 57.
} 
mesmo nas revistas de auto-ajuda para executivos, mas o ponto é justamente que se trata de auto-ajuda, ou seja, de voluntarismo estético - e impulsionava a expansão do capitalismo na fase do liberalismo aventureiro, é tornada obsoleta seja pela posição administrativa e distanciada que é exigida pela concentração e pelo monopólio, seja pela submissão irrestrita e otimista que é recomendável aos que não estão no comando. Não que, por outro lado, nas eras passadas do capitalismo, a subjetividade não fosse um artefato ideológico: o discurso universalista do longo século XIX, centrado nas capacidades ético-produtivas do sujeito, tinha sido eficaz para combater a ideologia religiosa aristocrática, mas revela seu efeito repressor no que é incompatível com uma problematização dos privilégios de classe engendrados pela sociedade burguesa. Despojado, portanto, de seu conteúdo crítico original à medida que a concentração de capital empurra a burguesia para longe de sua fase liberal, a noção já envelhecida de sujeito se faz presente no imaginário reificado do capitalismo tardio enquanto imagem do nexo das aptidões à tortura do trabalho, à resistência resignada, à satisfação indefinidamente postergada: as qualidades do herói do filme são idênticas às que a experiência estética do espectador exige dele, e também às que, findo o filme, e de volta ao trabalho, ele terá que demonstrar.

\section{Teoria estética}

A caracterização desse momento histórico contemporâneo em que, por um lado, é notada a identidade entre os conteúdos estéticos e os extraestéticos mas onde, ao mesmo tempo, essa identidade é criticada e, portanto, sub-repticiamente anteposta a uma não-identidade, parece pressupor um momento histórico anterior onde se dava uma distinção mais nítida entre o estético e o não-estético. De fato, as alterações históricas da natureza formal da ideologia, do conteúdo da cultura e da arte, e da organização socioeconômica, estão mapeadas em Adorno, e podem ser analiticamente ressaltadas sem prejuízo para a especificidade de sua teoria. Para começar, é necessário entender que, formalmente, o momento estético em geral - e a arte em particular, quando ela pode ser diferenciada desse momento estético, que hoje pretende cobrir quase toda a existência social quotidiana é, ele mesmo, construído numa tensão para com uma realidade empírica que está fora dele. $\mathrm{O}$ encanto do sentido, o discurso legitimador, a abundância agressiva do formidável, a ostentação de significados, tudo isso se delineia, 
logicamente, em oposição àquilo que deverá ser por tais elementos abarcado, legitimado, ornado e resgatado. Sem esse momento do resgate e do ornamento, o momento estético desaparece; entretanto, a reapresentação estética como ideologia não funciona sem a confusão entre o resgate e o resgatado: sem a objetivação do ornamento ${ }^{61}$, a qual é, ela mesma, um recurso estético. Por outro lado, historicamente, a diferença entre o artístico e a realidade empírica é marcada por processos que expressam essa separação entre o estético e o não-estético em termos de instituições sociais. Um exemplo claro desse processo é a autonomização da arte frente às suas funções de culto: o delineamento de uma esfera específica do estético, a ser compreendida por categorias estéticas suficientes, por exemplo, para julgar a qualidade de uma obra independentemente de sua relação com um conteúdo religioso que, não obstante, ela pode ou não expressar. A relação entre a arte e aquilo que ela, historicamente, vai deixando de ser, é também uma relação de negação e de contraste frente ao existente, de modo que os aspectos formal e histórico não podem ser realmente separados: "a arte adquire sua especificidade separando-se daquilo de que ela se desenvolveu; sua lei de movimento é sua lei formal" (AT 3 / 12). Que a lei formal - a forma especificamente artística de relacionar-se com o real - seja não apenas inseparável de sua lei de movimento - o comportamento histórico da esfera do estético -, mas idêntico a ela, significa que o modo específico da arte de se delimitar socialmente passa para a maneira como as obras de arte mesmas se organizam; e que essa delimitação social seja sobretudo negativa, significa que a obra de arte, ao mesmo tempo que está em tensão com o existente, está indissoluvelmente ligada ao existente justamente devido a essa tensão. O intrincadíssimo problema dialético que Adorno coloca é que a arte em sentido enfático, a realidade estetizada, o mundo empírico em sentido amplo, a esfera estética comercializável, a ideologia da estetização, tudo isso seja pensado simultaneamente numa constelação de implicações mútuas, sem qualquer ponto de partida isento desde o qual empreender a análise crítica - a qual, no âmbito estético como no filosófico, é parte do problema. Esse traço "impiedosamente autocrítico" (DN 15) marca o interesse específico do pensamento adorniano.

61 "O esquema da cultura de massas", p.67. 
A confluência entre os aspectos formal e histórico de determinação da esfera estética culmina em que "a revolta da arte, teleologicamente posta em sua 'atitude com respeito à objetividade' frente ao mundo histórico, tornou-se uma revolta contra a arte" (AT 3 / 12). Em termos históricos: o advento burguês da arte dissociada do culto religioso - a arte chamada "autônoma" - tem sua culminância na crítica que a arte, no período áureo da sociedade burguesa, fazia a essa sociedade ${ }^{62}$; com o modernismo, a própria posição privilegiada desde onde essa crítica era feita entra em questão; e esse impulso autocrítico é indissociável da explosão da esfera estética e da infiltração recíproca entre ela e o resto da vida social. Isso porque a negação da realidade empírica pela elaboração ou mediação do esforço estético formador repete, em certo sentido, a lógica da realidade empírica. A separação da obra frente ao que ela não é se realiza, a princípio, pelo estabelecimento de uma finalidade própria ${ }^{63}$ ou de uma auto-identidade que "sublima" a autocentralidade do mundo empírico, repetindo-a numa oposição entre finalidades distintas: a "compulsão à identidade" do real é contestada por uma identidade que procura estabelecer "uma relação entre todo e parte de acordo com as necessidades da própria obra", de modo a “ajudar" o não-idêntico (AT 4 / 14). Mas a "força estética de produção é idêntica àquela do trabalho produtivo, e possui a mesma teleologia" (AT 5 / $15)^{64}$, de modo que, assim como a produção pode se dissociar da satisfação das necessidades, tornando tudo aquilo que lhe é externo um mero momento de sua afirmação, o estético tem a tendência intrínseca de automatizar sua teleologia, repetindo, no plano estético, a lógica da gratuidade do empírico. A síntese desse quadro é o real que é sua própria ideologia: absorvendo completamente o caráter de coisa, a arte se torna a mera repetição do conteúdo empírico dado, o qual, por sua vez, tem sua empiricidade bruta transformada numa empiricidade elaborada, uma cultura naturalizada.

Não obstante, ao longo da sua discussão, Adorno enfatiza o momento crítico da obra de arte tanto no período da arte burguesa clássica quanto no da arte moderna. Da mesma forma que a tendência reificadora

\footnotetext{
62 "O esquema da cultura de massas", p. 67.

${ }^{63}$ Adorno relaciona-se, aqui, à terminologia kantiana: trata-se do Zweckmäßigkeit da Terceira Crítica.

${ }^{64}$ A sentença continua: "...e o que pode ser chamado relações estéticas de produção - tudo aquilo em que a força produtiva está presente e ativa - são sedimentações ou impressões das relações sociais de produção."
} 
ideológica que lhe é oposta, essa capacidade crítica também está dada logicamente: a esfera do estético proporciona a aparição dos conteúdos que mobiliza, de modo que uma autocrítica estética consistiria em denunciar a aparição como mera aparição, fazendo aparecer os próprios processos de produção da aparição. Assim, romper-se-ía o tabu sobre a produção que é causado pela realidade estetizada. Mas o fato mesmo de que esse tabu é rompido apenas no domínio da aparência cria problemas que minam a razão de ser do projeto cognitivo da arte moderna como um todo. De fato, Adorno sugere que a autocrítica do caráter de representação do estético, enquanto sinal reflexivo de sua autonomia, repete, no nível da representação autônoma, o duplo caráter da arte enquanto formalmente autodeterminada e historicamente determinada pelo não-estético ${ }^{65}$, uma vez que "os antagonismos da realidade retornam nas obras como problemas imanentes da forma" (AT $6 / 16$ ) - o que, aliás, está posto pelo caráter negativo intrínseco da arte e sua dupla determinação na relação de mediação do real simplesmente dado. Isso significa que é preciso ler na autocrítica à representação uma expressão formal dos problemas da produção, e não apenas sua tentativa de solução. A arte não é isenta: é parte do problema.

Historicamente, a autocrítica da representação empreendida pelo modernismo tem um teor de crítica da ideologia: tratava-se de combater a aparência de reconciliação proporcionada pela arte burguesa, numa época em que os potenciais modernizadores dos capitalismos nacionais já se haviam exaurido, e a violência imperialista começava a ser deflagrada. Ao mesmo tempo, esse projeto esforçava-se por resistir à apropriação comercial da arte que teve lugar no período imediatamente anterior. O ponto de encontro entre as duas tendências é a sofisticação da forma: quanto mais aparece a forma, mais se torna evidente que a arte não é uma representação do real, mas uma apresentação do próprio estético e, assim, mais os processo estéticos produtivos são anunciados e, num mesmo movimento, denunciados como mera aparência; ao mesmo tempo, quanto mais distante a substância da obra está dos conteúdos explícitos da experiência empírica, menos a experiência estética envolverá um sorver relaxado da imediatidade digerida, e mais tratar-se-á da continuação regurgitativa da digestão difícil da realidade por um esforço espiritual que a encontra alheia, impermeável,

\footnotetext{
${ }^{65}$ Nos termos do próprio Adoro: "autônoma e fait social". AT 5 / 16.
} 
opaca. O formalismo, contudo, contém uma dialética pouco sutil: se, desde o ponto de vista isolado da elaboração estética, o mundinho quotidiano aparece como aquilo que está simplesmente ou imediatamente dado, ou o material desde o qual a mediação artística partirá para delimitar o espaço específico e separado do estético, esse mundinho empírico é, desde sempre, já um lugar da elaboração formal e da submissão da experiência às categorias do sujeito - em última análise, do sujeito automático absoluto do capital, que já organizou todo o conteúdo empírico em termos da troca, da mediação, do valor. Se a elaboração formal cai sobre as coisas com a prepotência apriorística que marca, historicamente, os elementos do modernismo que foram herdados do ufanado romantismo triunfalista (nas modalidades nacionalistas e tecnófilas) ou do humanismo choroso (em continuadores obstinados do romance, como Thomas Mann), a lógica do real é repetida. O procedimento de tal formalismo, considerado abstratamente - ou seja, em sua forma - descreve tanto a onipotência do produtor de mercadorias culturais que manipula o conteúdo da obra para que ela atenda o esquema comercial palatável e esperado, quanto o comportamento da música dodecafônica, sofisticada ao absoluto, que, no limite, préorganiza o material musical a tal ponto que a manipulação dos sons torna-se uma repetição do procedimento industrial ${ }^{66}$. Essa onipotência do formalismo consiste em um dos lados da dialética que Roberto Schwarz salienta em algumas de suas breves porém loquazes considerações sobre a crise do sujeito criativo burguês: por um lado, ela "deriv[a] de impulsos políticos, libertar do nexo particularista, i. e. capitalista, as forças produtivas"; por outro lado, e ao mesmo tempo, a "posição e linguagem do individualismo burguês [são] desmentidas no interior do próprio capitalismo" pelas exigências mesmas da massificação da cultura ${ }^{67}$, expressão e conseqüência - conforme já sugerido - da concentração de capital e da instauração do monopólio como sua unidade funcional, antagônica ao pequeno empreendedor aventureiro. Aquilo a que Schwarz se

\footnotetext{
66 T. W. Adorno: The Philosophy of Modern Music. Trad.: A. G. Mitchel e W. V. Bloomster. London: Sheed and Ward, 1973, pp. 98-99, e E. Lunn: Marxism and Modernism. London: University of California Press, 1982. pp. 261-262. Com esse argumento, o presente autor gostaria, ainda, de haver tangido e atacado, ainda que levemente, as interpretações que enxergam no Adorno um reclamão elitista apegado à incognoscibilidade per se da alta cultura.

67 "Nota sobre vanguardismo e conformismo" in O Pai de Família, p. 46.
} 
refere com a expressão "impulso político" consiste no potencial do capitalismo que, embora se tenha deixado escapar ${ }^{68}$, impulsionava sua crítica imanente: o desenvolvimento das forças produtivas e a obtenção de capacidades técnicas capazes de abolir a necessidade material, e apontavam para a superação da propriedade privada dos meios de produção.

Mas já se trata da "época da superprodução", na qual "o valor de uso da mercadoria se tornou questionável, sendo suplantado pela gratificação secundária do prestígio, do estar na moda, e, finalmente, pelo próprio caráter da mercadoria, numa paródia da aparência estética" (AT 17 / 33). Essa intimidade entre o caráter da mercadoria e a dimensão estética afeta internamente o pathos do formalismo. Aquilo na arte que exige que a esfera do estético seja reconhecida como infinita em seu gênero, e que a aparta do meramente dado através de uma "negação abstrata" (AT 6 / 16), tem algo da arbitrariedade da iguaria cultural, e do elitismo que daí decorre. E justamente porque se trata, aqui, de um fetiche intelectualista, a tendência que produz como resultado essa concepção estetizada do estético não é separável de alguma arte mais verdadeira e mais legítima através de alguma estratégia a priori. Essa forma de uma relação para com as coisas que é desencadeada por uma lógica própria, uma pulsão absoluta, independente das coisas, é aquilo que, na obra de Adorno, é designado pelo termo "dominação", e que é o resultado autoritário da perpetuação, pelo capitalismo tardio, da funcionalidade tecno-produtiva enquanto algo dissociado da satisfação das necessidades.

Se, com isso, torna-se visível que o problema do estético não é, ele mesmo, um problema estético, mas evoca o problema da lógica da produção material em geral, também fica indicado o quanto o problema da produção não é unicamente um problema de produção. $\mathrm{O}$ conceito de dominação, que marca o autoritarismo da forma estética em referência ao emprego autonomizado das forças produtivas, incide sobre a concepção simplista da teleologia do desenvolvimento tecnológico: a concepção, empregada por diversos marxismos em suas interpretações do conteúdo do socialismo e da revolução, de que a própria produção, como uma esfera específica, contém

68 É o que está sugerido numa alusão a uma formulação de Marx, na primeira frase da introdução da Dialética Negativa: "Philosophie, die einmal überholt schien, erhält sich am Leben, weil der Augenblick ihrer Verwirklichung versäumt ward." ("A filosofia, que outrora pareceu ultrapassada, segue vivendo, porque se deixou passar o momento de sua realização.") (ND 15). 
os princípios de solução dos antagonismos sociais do capitalismo. Para efeitos da presente discussão, o que é especialmente significativo é que se torna preciso compreender de forma enfática a tese adorniana de que os antagonismos sociais se repetem na esfera estética. A produtividade do estético não soluciona o problema da delimitação da esfera específica do estético, assim como a produtividade técnica, por ela mesma, não levou à superação das relações capitalistas de produção e à abolição da necessidade material. Também fica claro, por outro lado, que a tentativa do modernismo artístico de fazer uma crítica à reconciliação estética e à mercadorização da arte precisa passar menos por uma concepção alternativa de arte do que por uma prática concreta de produção estética. Ademais, visto que a relação entre a produção e o seu princípio lógico é parte do problema da produção autocentrada sob o capitalismo tardio, e que esse problema pode repetir-se na abordagem teórica mesma que faz um discurso sobre a arte, é preciso dizer que "hoje é adequado aproximar-se da arte, kantianamente ${ }^{69}$, como se ela fosse um dado"70 pois "quem advoga sua causa fabrica ideologias e faz da arte uma delas." Em outros termos: a arte é - contanto ou na medida que sua descrição mesma seja uma crítica da ideologia. O pensamento sobre a arte tem que buscar "algo na própria realidade, algo que esteja atrás do véu que é tecido pela interação das instituições e das falsas necessidades", e essa busca "exige uma arte que fale por aquilo que o véu esconde." (AT 18 / 35). A possibilidade de um conceito crítico de arte é a possibilidade da própria arte $^{71}$, mas não como algo sustentado pelo conhecimento, e sim como um

\footnotetext{
${ }^{69}$ A alusão, aqui, é ao método de crítica transcendental. Na Crítica da Razão Pura, conforme se pode depreender já dos Prefácios e Introduções da primeira e segunda edições, tratava-se de responder à seguinte pergunta: visto que a física e a matemática são ciências que funcionam, progridem, e obtém resultados prático-teóricos, o que é que as torna possíveis? A analogia com a estética, sugerida por Adorno, teria o sentido de dizer: dado que a arte existe, o que a torna possivel? Pode parecer curioso que essa abordagem seja a escolhida por um autor que - muito ao contrário de Kant, que tinha a física e a matemática como pontos cegos filosoficamente inquestionáveis em seu conteúdo específico - está todo o tempo questionando a possibilidade da obra de arte. Mas o ponto, conforme talvez a presente exposição tornará visível, é que o problema da possibilidade é um problema interno à obra de arte. Como sempre, com Adorno, o buraco é mais embaixo.

70 A discussão que Adorno empreende ao longo da Teoria Estética está, de fato, sustentada por numerosas análises de obras. Os nomes que mais freqüentemente desempenham o papel de exemplos do que o autor quer dizer com seu conceito enfático de arte são Beckett, Kafka e Picasso. Adorno de fato planejava dedicar a obra a Beckett (Aesthetic Theory, p. 366).

71 De fato, numerosas vezes ao longo da Teoria Estética, Adorno afirma que a arte em sentido enfático não se realiza enquanto tal exceto através da interferência de uma teoria estética.
} 
objeto radical dele. Não é exagero sugerir que nessa colocação do problema está condensada toda a problemática da filosofia adorniana ${ }^{72}$. Trata-se de, através do discurso (uma teoria estética) descrever um objeto que, através da descrição, não seja absorvido pela descrição - para evocar a dialética negativa: um objeto que mantenha sua objetividade frente ao pensamento identificador que tenta se oferecer em troca do objeto que identifica, o que, evidentemente, não pode ser alcançado através da maneira como a teoria sobre objeto será feita - o que equivaleria a sustentar a objetividade apenas através da teoria - mas encontrando aquilo que, no objeto, é capaz de resistir à teoria. Ora, o que possibilita tal procedimento teórico é, então, o próprio objeto - a arte - a qual, por sua vez, é ela mesma uma fabricação, uma maneira peculiar de organizar a apresentação de conteúdos. Aquilo com que a arte se relaciona, o mundo empírico, devido ao seu próprio conteúdo estetizado, não atende a exigência de uma objetividade radical e não-ideológica; é a arte mesma, o objeto da teoria estética, que vai cuidar de desideologizar a realidade, elaborando-a num conteúdo artístico, o que, a seu turno, tornará possível à teoria estética a apresentação de um objeto. Trata-se de alcançar a objetividade através de um procedimento reflexivo ${ }^{73}$, no seio do qual, entretanto, está a negação da reflexão: porque a arte mesma - como se depreende da discussão sobre o formalismo - não pode ser

\footnotetext{
72 Isso é ilustrado pela obra "Selbstportrat", incursão de Adorno na arte da fotografia. Trata-se de um retrato estreita em orientação vertical de um espaço doméstico no meio do qual está um grande espelho vertical de corpo inteiro. No espelho, vê-se o reflexo de Adorno sentado em um banco com um disparador de câmera fotográfica na mão. A câmara está visível atrás do banco, virada para o espelho. A foto é um foto que mostra não só o objeto do retrato, e a câmera que tira o retrato, mas também 0 espelho onde o objeto e a câmera se refletem, sendo que, ademais, o objeto é o sujeito, que aparece espalhado: ele está sentado no banco, ele está no poder organizador que dispõe a câmera mesma, e, também, no espelho. Tudo isso é situado objetivamente dentro do cenário interior meio doméstico: a imagem do espelho não é toda a imagem, mas uma parte dela apenas. 0 ponto não é fotografar a si mesmo, e tampouco fotografar a si mesmo e à câmera (algo que estaria no nível reflexivo do Idealismo Absoluto de Hegel), mas apresentar como foto todo o processo autofotográfico - o que, aliás, é autocontraditório, porque a fotografia dá instantâneos, e um processo é, por definição, o oposto do instantâneo. Assim, enquanto foto do processo, "Selbstportrat" é retrato da contradição.

${ }^{73}$ Abstratamente, isso se oferece como uma continuação direta do projeto do idealismo alemão especialmente e sobretudo de Hegel, uma vez que o sujeito-objeto do procedimento reflexivo não é a própria razão, mas algo que se poderia chamar de espírito objetivo - do conteúdo sócio-representacional - que se esforça por delinear-se em oposição à razão, realizando melhor que ela suas promessas. Concretamente, entretanto, o papel que o momento histórico-sociológico - a segunda natureza nãoespiritualizada - desempenha no pensamento adorniano afasta-o de Hegel e da tradição idealista, o que aparece como um momento interno da teoria estética, e da própria arte, que é sempre "apenas" arte: 0 inverso do absoluto.
} 
reflexiva e continuar comportando-se de forma anti-ideológica na realidade estetizada. É como se o único conhecimento positivo possível - em contraste com o conhecimento negativo proporcionado pela mó da dialética negativa - fosse a estética, e o único objeto de conhecimento possível fosse a arte, que se constitui enquanto tal através de sua lida peculiar com o real. Em outros termos: a teoria estética - em letra minúscula, entendida como a forma de procedimento teórico de que fala o livro de Adorno - implica uma dupla crítica: a da teoria que, diante das ideologias sobre a arte, atinge algo que não é ideologia, e a da arte que, diante dos objetos estetizados do mundo empírico, é capaz de despojá-los do seu véu.

As exigências de toda essa formulação malabarística fazem com que essa capacidade da arte de despojar as coisas de seu véu estetizado não dependa apenas do que é a arte, mas do que é o véu. Segundo um dos aspectos da análise do esquema da cultura de massas, esse véu é o tabu sobre as relações de produção, mas, como se depreende da crítica ao formalismo, a maneira adequada de questionar esse tabu não pode ser absolutizando um procedimento novo de produção que lide com as coisas desde um ponto de vista que sempre as deixe a salvo. A estetização, portanto, não pode ser criticada e destruída por um conceito de arte, mas nesse contexto - apenas dentro das obras de arte, e nos próprios termos colocados por cada uma das obras. Não obstante, isso dita uma forma geral para a totalidade da obra em relação aos seus momentos, a qual, contudo, não pode ser preservada se não pela relação específica entre o teor dessa totalidade e cada uma das partes que a obra organiza: essa forma deve ser tal que o todo da obra - seu sentido total, seu princípio concreto de coerência $^{74}$ - não caia sobre as partes como uma lei que lhes seja externa, mas brote desde baixo, desde as exigências intrínsecas das partes.

Ora, o material fundamental para esse procedimento de formação estético deve partir do mundo empírico. Mas os pedaços de um real administrado, dominado, submetido à produção autocentrada e completamente estetizado certamente carregarão em si a mácula de sua sujeição heterônoma. Como, então, buscar - conforme diz Adorno - "na

74 O qual, ao longo da Teoria Estética, é designado "Zusammenhang" - essa palavra de significado multifacetado e de teor algo místico para um lusófono. 
própria realidade" o ponto de partida para a arte que possibilita a dupla crítica da ideologia?

A interpretação do pensamento adorniano e da realidade estetizada que inclui em si um sorriso torcido diante dessa pergunta, e que, então, desbarata todo o esforço teórico com uma alusão à alguma típica impotência frankfurtiana e ao "Grande Hotel Abismo", do qual pretende ser a acusação, pois se rende a uma caracterização a priori da realidade como absolutamente cerrada em si, enquanto que nenhuma caracterização desse tipo pode ser possível. O esforço de realizar a administração absoluta, inclusive a do mundo interior, não teria sentido específico se não houvesse aquilo cuja externalidade com respeito à administração tivesse que ser superado e que resiste, a princípio, a esse esforço: algo que, no mais das vezes, sucumbe terrivelmente, mas esperneando. Aquilo que, na própria realidade, representa a margem intrínseca da autocentralidade da produção de necessidades, o "não factual na facticidade" (AT 86 / 134), é o sofrimento. É este o material da arte que está no centro da crítica ao real que é ideologia de si mesmo ${ }^{76}$.

Não quer dizer que o sofrimento é uma verdade pulsante e essencial no meio do descaminho desumano do capitalismo tardio. $\mathrm{O}$ sofrimento não é uma pedra de toque de realidade fora da rede de estetização: ele é efeito dessa rede, por um lado e, por outro, conteúdo dela: é evidente que não faltam esforços na produção comercial de aparências para expressá-lo, abarcá-lo, enlatá-lo e vendê-lo. De modo que o que interessa à teoria estética não é o sofrimento como conteúdo, mas como forma - o que, aliás, retoma o tema do modernismo formalista sob outra luz. Essa forma é aquele teor próprio ao sofrimento que, na experiência empírica, desaparece sob os esquemas de apresentação do real ideologizado: na medida que esse teor reaparece na arte, ele é ao mesmo tempo artístico e não-artístico. Não se trata da produção de um consolador dispositivo representacional que proporciona a oportunidade de chorar esteticamente as mágoas que não encontram expressão numa realidade endurecida. A arte não consegue sair dessa realidade, olhá-la desde o alto com superioridade, piedade e isenção: como ela mesma consiste, também, em uma espécie de domínio formal

\footnotetext{
${ }^{75}$ A expressão é de G. Lukács, Theory of the Novel. Cambridge: MIT Press, 1971, p. 22.

${ }^{76}$ C.f. "Sprache des Leidens" ("Linguagem do Sofrimento"), AT 18-19 / 35-36.
} 
sobre um material, a obra de arte que fala do sofrimento como forma é aquela que imanentemente critica seu próprio momento de domínio sobre aquilo que está sob o signo da sua unidade - e critica-o através disso que ela domina. A obra de arte - nesse sentido enfático - implica, por essa autocrítica, o aparecimento de um paradoxo: ela abre o espaço para "algo que nem pode ser separado de seu aparecimento [na obra] nem pode ser considerado idêntico a ela" (AT 86 / 134). Ao mesmo tempo, no que se critica radicalmente, e se abre para a contingência da sua unidade frente aos elementos que articula, a obra de arte também se precariza.

Essa precarização é em si mesma dúbia. Por um lado, trata-se de anular a identificação entre o belo e a arte, ou seja, a obra passa a incorporar o feio. Sua unidade frente ao mundo empírico deixa de estar garantida por uma alternativa de coesão reconciliadora que deixa aquele que usufrui da obra embevecido e enrolado em um rocambole de emoções e, ao contrário disso, precipita-o em um desconfortável caminho que está menos para o sentimental que para o cognitivo, e, assim mesmo, repleto de obscuridades, dúvidas, incognoscibilidades. Por outro lado, a obra que assume a precarização pelo feio parece afrouxar as exigências sobre si própria, e através do vale-tudo estético que se estabelece, se aproxima de um poder quase irrestrito de manter qualquer sorte de coerência esdrúxula frente ao que quer que seja. A incorporação da dissonância pela música moderna, e o descarrilamento dessa música em direção à dominação a priori das seqüências sonoras de doze tons, ilustra tão bem essa problemática quanto a psicodélica cultura comercial pós-moderna que, em certo sentido, estava pré-figurada na colagem surrealista ${ }^{77}$. A abertura da coerência estética para o dissonante, e sua dissolução numa dadivosa confiança abstrata no sentido intrínseco do particular fragmentado que é, assim, precariamente reunido na obra, resulta numa ideologização do particular. A estética da sucessão desvairada de imagens quotidianas, hoje lugar comum da publicidade, mostra o sentido em que essa dimensão da precariedade artística funciona: trata-se da submissão a uma ideologia imediatista do particular, uma valorização a priori do individual, como se a sua importância, seu sentido,

77 C.f. T. Adorno: "Retrospectiva sobre el surrealismo" in Notas sobre literatura, I (Obra Completa, 11). Madrid: Akal, 2003. A idéia também está sugerida em "O esquema da cultura de massas", p. 59. 
sua plenitude, estivessem dados no mundo: é um individualismo comunitarista em tempos de autoritarismo monopolista ${ }^{78}$.

Essa reafirmação do fragmento como a verdade do particular, contudo, trabalha no sentido oposto à mecânica representacional que quer pôr o sofrimento em evidência. Porque o sofrimento como forma é a voz do que perece sob a administração absoluta e, portanto, é inimigo do sentido enquanto dominação do particular. Não obstante, essa inimizade só aparece no contraste mesmo ou na resistência específica - alcançada apenas no plano da representação - frente à aniquilação, e não por uma alternativa à aniquilação. Se, em determinados contextos - por exemplo, Baudelaire escrevendo sob o impacto da Comuna de Paris ${ }^{79}$ - a incorporação imediata do feio alcança o resultado da representação particular capaz de antepor-se ao obscurantismo ideológico, isso se dá pelo respaldo sociopolítico com que a obra pode contar (a respeito do qual haverá espaço para dizer certas palavras de importância); na falta deste, e em presença do esquema ideológico que se baseia na visibilidade, o sofrimento só pode aparecer como crítica da própria visibilidade. Significa que a visibilidade mesma tem que aparecer e ser questionada: trata-se de um sofrimento que "coloca à prova a significação" (AT $153 / 230)^{80}$.

Mas essa formulação não dissolve o paradoxo: apenas o renova. Porque, ao mesmo tempo, esse colocar à prova só é alcançado através da coerência interna de sentido da obra, ou seja, do significado. Essa dimensão não pode ser simplesmente anteposta à violência da dominação formal, como se lhe fosse um inteiramente outro. "A arte participa na culpabilidade do que está vivo não apenas porque sua distância permite que a culpa prevaleça, mas porque - o que é mais importante - ela corta o que está vivo

\footnotetext{
78 "...na opinião do Autor - aliás, uma legião deles - vivemos numa Kulturgesllschaft, numa sociedade na qual a experiência e a prática culturais se tornaram a principal fonte ou 'agência' (outra palavra chave do jargão) socializadora, ao contrário das macro-identidades herdadas da finada Era Industrial, como 0 Estado, a sociedade nacional, os partidos políticos, a relação salarial, etc." - "...hegemonia cultural hoje não se assemelha mais a uma fábrica hierarquizada produtora de ilusões e consensos extorquidos, decorre, pelo contrário, de um sistema altamente diferenciado de interações em mão dupla. Uma hegemonia flexível, enfim, na qual se exprime a revolução cultural do nosso tempo, a elevação do consumo de massas às altas paragens do espírito." P. E. Arantes: Zero à esquerda. pp. 198, 200.

${ }^{79} \mathrm{Na}$ leitura de Dolf Oehler: O Velho Mundo Desce aos Infernos. São Paulo: Companhia das Letras, 1999.

80 De fato, essa observação é feita no contexto de um defesa de Beckett contra a designação de absurdista.
} 
em pedaços de modo a alçá-lo à linguagem e, assim, o mutila." (AT 144 / 217). Isso reverte em um novo ataque à ideologização do fragmento e do particular: o discurso que decai em um elogio à diferença sacramenta ideologicamente a dominação e o massacre final da diferença pelo discurso que a torna palatável e compatível com o mundo onde a sufocante visibilidade institucionalizada, para início de conversa, era justamente o que tornava politicamente necessária a idéia de diferença.

Não quer dizer, entretanto, que está dada uma continuidade entre a dominação estetizada que tem lugar naquilo que, sob o capitalismo, só se chama de sociedade por escárnio, e a elaboração formal dentro da obra de arte. A dominação estética consiste na elaboração discursiva da dominação de tal modo que, com a bênção da aparência e da visibilidade, ela se torne insuportavelmente tolerável: a dominação estética no real extra-estético é a estetização da dominação. Em contraste, o estabelecimento da coerência formal nas obras de arte é coerência formal enquanto forma que aparece: como o resultado dessa coerência é a ilusão e o jogo, o aparecimento dos seus meios de produção a denuncia enquanto tal ${ }^{81}$. O limite desse contraste é, não obstante, que, se a dominação é um traço da realidade, a forma estética que organiza as obras de arte não pode ser rigorosamente isolada enquanto forma - ou seja, enquanto processo racional autônomo que brota do espírito genial de algum diletante de bom-gosto: ela está no mundo empírico e, portanto, é uma modalidade de "conteúdo sedimentado" (AT 144 / 218) do mundo empírico. Assim, o paradoxo persiste, mas seu sentido é revertido em favor da elaboração formal que, afinal, não é tão formal assim: ela não sobrecai àquilo que está formalmente organizado, mas é o refugo estético de um processo social de organização. "Aqueles traços da arte radical que a fizeram ter sido ostracizada como formalista derivam, sem exceção, de um conteúdo encarnado que nela se debate sem ter sido peremptoriamente ajustado por uma harmonia facilmente vendível." (AT 145 / 218). A relação antagônica entre e o real estetizado e o espaço estético propriamente dito - determinado pelas obras de arte que Adorno toma como um fato - recebe uma formulação especificamente estética, e reaparece

\footnotetext{
81 Em termos do jargão hegeliano: "A mediação [que as obras de arte realizam], implicitamente contida no empírico, torna-se o para-si da consciência apenas através do ato de dar-se diante dela um passo atrás, que é o que a arte faz." (AT 145 / 218).
} 
como uma antítese entre a ressuscitação artístico-formal do conteúdo sedimentado da dominação como sofrimento, e o conteúdo simplesmente dado do real estetizado. Essa antítese se traduz também em considerações sobre obras de arte: aquelas que tentam reapresentar imediatamente o conteúdo do real fracassam enquanto obras, e permanecem dispositivos estéticos do mundo extra-estético. "O que é socialmente decisivo nas obras de arte é o conteúdo que se torna eloqüente através das estruturas formais da obra" (AT 230 / 342), as quais exibem enquanto mecânica especificamente estética o que, no real estetizado, passa como simples segunda natureza.

Isso equivale a um reaparecimento da constelação do problema estético com o problema do conhecimento, a qual foi o mote inicial do presente relato sobre o pensamento adorniano. No que a forma que é "emancipada" pela obra de arte "se recusa a mitigar a alienação na imagem", a arte "é capaz de incorporar o alienado" enquanto tal (AT 145 / 230). O comportamento especificamente estético na obra de arte moderna acaba exercendo assim, frente à realidade estetizada, uma função cognitiva, pois o espaço estético parece distanciar-se do real estetizado segundo o mesmo comportamento que separa, daquilo que é, um juízo que diz o que é. A verdade do mundo cuja falsidade consiste em sua repetição ilusória é a verdade da ilusão, ou a repetição do falso. A expressão "teoria estética", nesse sentido, denota não uma teoria sobre a arte, mas uma teoria artística, ou uma arte teórica. Só que o curioso e - novamente! - paradoxal resultado dessa teoria estética é que, por um lado, o aspecto do formalismo que contribui para que a obra de arte seja estranha e se mantenha sempre à distância é combatido enquanto princípio a priori para a produção de obras, mas, por outro lado, acaba sendo recuperado como traço interno de obras de arte já existentes: ou seja, o formalismo é negado a priori mas é recuperado a posteriori. E se é verdade que a diferença entre esses dois modos de ser do alheamento formal é significativa, também é verdade que o resultado desse alheamento, ainda que a posteriori, é uma rejeição sumária da realidade uma rejeição concreta e interna, mas sumária. A razão de ser do pensamento adorniano parecia ser expressa pelo esforço por apresentar as mediações subterrâneas de uma realidade que, através de sua repetição no campo da representação, media sua imediatidade, ou produz o obscurecimento da produção; mas o resultado de tal esforço de apresentação relaciona-se com a mecânica de apresentação do próprio esforço de maneira negativa: a rejeição do real supera teoricamente o papel que o real desempenha nessa 
rejeição. Em outros termos: se o fundamental é que a teoria não pode resolver problemas que não são teóricos, e que a tentativa - e o sucesso - da aparência em sentido amplo de absorver os conflitos do real deve ser criticada por uma apresentação denunciatória desses mecanismos mesmos, como admitir que o resultado da teoria seja a apresentação teórica de mecanismos representacionais? Como aceitar que a culminância do processo de desencantamento da aparência e de rompimento do esquema racional de dominação seja o próprio procedimento teórico-aparenteracional de negar esses objetos teóricos como falsos? Por que o esforço de furar a malha estetizante da aparência, ao invés de se dar no plano da aparência, não é uma injunção prática à transformação do mundo onde, por motivos extra-estéticos, a estetização impera?

\section{Engajamento}

Aqueles críticos que pressentem que a ênfase adorniana no momento negativo tem um sentido político estão certos; mas erram quando, com base nisso, o denigrem como pessimista-elitista-conformista. A exigência de que a crítica adorniana à sociedade estetizada tenha como resultado uma posição política extra-estética está minada em suas próprias bases, e embora a causa de que seja assim esteja apontada pela crítica adorniana da representação, as conseqüências transcendem qualquer adornianismo, e podem ser sentidas examinando-se o que é que se tornou a esquerda realmente existente. Cobrar de uma construção teórica uma prescrição política específica com base na objeção de que aquela construção não pode permanecer autocentrada é pedir por uma autocentralidade ao quadrado, porque a relevância política de uma teoria não pode ser garantida, enquadrada, sustentada e estabelecida pela própria teoria. As condições do fazer político e do fazer teórico são distintas. Na experiência social concreta, o discurso dos revolucionários $a$ priori e do ativismo, ou a estupidificação apologética da teoria realizam o desconhecimento disso na prática, e se alinham à demanda do mundo administrado segundo a qual "é preciso tomar parte" 82 .

82 "Man soll mitmachen". T. Adorno: "Resignation" in Stichworte. Kritische Modelle 2. Gesammelte Schriften 10.2. p. 795. 
À luz dessas observações, é preciso retomar o percurso da presente apresentação e levar a sério o fato de que a posição adorniana não é uma rejeição de toda práxis através de uma filosofia negativa da representação, mas uma filosofia negativa da práxis construída sobre uma sociologia da representação cujo cerne é uma crítica radical da economia política que recusa insistentemente todo compromisso com as estruturas lógico-práticas do capital e que, por isso, abre espaço teórico para a reflexão sobre o fracasso da política tradicional de esquerda, batendo de frente nesse aspecto de auto-ajuda que determina a fácil positividade política da falsa representação teórica da política, tanto entre os pós-modernos que reduzem a política ao texto, quanto à ontologia que quer fundamentar no texto a possibilidade da política. $\mathrm{O}$ resultado da incorporação do fracasso político pela teoria é que ela consegue continuar sendo crítica mesmo quando não há perspectivas práticas imediatas; e o contrário disso é depor as armas da crítica sem, no entanto, ser capaz de comprometer-se com nada que não seja uma crítica insuflada porém desarmada cujo efeito se limita à satisfação narcísica daqueles que a praticam.

Quando se fecha a essa tensão entre teoria e práxis, ou quando interpretado sem levá-la em conta, o pensamento adorniano perde qualquer resquício de interesse específico, e se torna um comentário sofisticado à brutalidade civilizada estabelecida a ser praticado por humanistas saudosos para despeito de leninistas saudosos e sessenta-e-oitistas saudosos. Mas a tal tensão não está realmente ausente da teoria da arte de Adorno: é, ao contrário, um de seus elementos fundamentais. Seu aparecimento neste contexto se dá através do problema da dominação na aparência.

A propensão à dominação, como atributo da razão - das instituições do saber e da técnica -, conforme discutido ao longo de toda a Dialética do Esclarecimento, é a marca do surgimento daquelas estruturas de produção e de organização e controle social que resultam no caráter autocentrado da produção sob o capitalismo tardio, na época em que o desenvolvimento técnico e a produção da abundância não levou à superação das relações sociais que administram a segregação, a repressão e a (falsa) escassez. A produção autocentrada determina a experiência social através da produção de necessidades, à qual está atrelada a incorporação do momento econômico do consumo pelo da produção. $\mathrm{O}$ caráter fantasmático da satisfação das necessidades que resulta disso condiciona o discurso a se comportar como mero comentário a uma realidade cuja visibilidade não precisa de ajuda 
externa, e que assume seus absurdos com fulgurante brutalidade. Esse realismo ilusório do capitalismo tardio determina traços formais dos produtos culturais, os quais se estruturam internamente como produtos da indústria. Dado o teor autocentrado da indústria, esses produtos precisam oferecer-se como o objeto correspondente a uma demanda que eles mesmos e a própria indústria colocam, o que significa que não pode haver, neles, nenhum momento de transcendência com respeito à sociedade onde eles aparecem. Como a vida mesma, a realidade fora dos produtos da indústria cultural, é objeto da produção estética, os produtos culturais simplesmente reapresentam os conteúdos estéticos do mundo extra-estético, de tal modo que a cultura de massa é fundamentalmente adaptação. Isso é efetivado através de uma disposição peculiar do conteúdo mesmo dos produtos culturais, a qual manifesta diretamente o princípio de organização da vida que permite que a própria experiência seja submetida a princípios de produção autodeterminada.

O que há de violento nessa submissão é que ela suprime o antagonismo entre a temporalidade da experiência e a atemporalidade dos procedimentos industriais, antagonismo este que está na raiz da já naturalizada conversão econômica do trabalho em trabalho abstrato. Esse antagonismo aparece no pensamento adorniano sob diversas formas: uma delas é a inadequação fundamental entre o discurso e seus objetos, problematizada na Dialética Negativa em termos da crítica ao princípio universal da equivalência. No interior dos produtos culturais, o procedimentos concreto que desempenha a função do princípio de equivalência é a relação entre a apresentação estética dos conteúdos extraestéticos e o sentido estético que essa apresentação toma. Como os conteúdos já vêem do mundo estetizados, sua apresentação é reapresentação, e o efeito específico de sua colocação dentro de um produto cultural não faz, para eles, a menor diferença. Um exemplo disso é o papel que as instituições e imagens da vida quotidiana desempenham no cinema: numa série de filmes sobre feiticeiros, os personagens apontam suas varinhas mágicas para seus inimigos, e ameaçam-se uns aos outros com elas, como se elas fossem armas de fogo, de tal forma que não existe um esforço no plano da representação fílmica de reconhecer a especificidade do fantástico naquilo que ele tem de incompatível com a realidade pretensamente desencantada. Da mesma forma, a tematização do casamento na televisão reproduz e desencadeia a série de situações logicamente 
contidas no conceito de casamento: problemas de paternidade, questões financeiras, competição e adultério. Um filme qualquer que dedica quarenta minutos para a apresentação da lida de um determinado personagem com o problema casamento tem que preencher os quarenta minutos com as estruturas lógicas que o esforço de raciocínio mais despretensioso poderia derivar do conceito de casamento em dois ou três minutos. A indústria cultural permite, em sentido literal, que se mate o tempo. Um minuto de filme não tem existência enquanto filme, mas enquanto o desvelar do conceito de algo socialmente reconhecível ${ }^{83}$, o que se deve ao fato de que isso que é socialmente reconhecível não tem conteúdo próprio enquanto experiência pois, no mundo onde as necessidades são produzidas, as categorias sociais têm uma relação externa e negativa para com a experiência mesma.

Ora, o relacionamento entre a teoria dotada de conteúdo político positivo a priori e a história manifesta essa mesma mecânica de submissão da experiência a um princípio produtivo. As duas dimensões aparecem objetivamente implicadas e condensadas na discussão sobre a arte engajada, e Schwarz mostra isso de maneira bastante clara em sua perceptiva análise da Santa Joana dos Matadouros de Brecht ${ }^{84}$. Schwarz observa que, nessa peça, as falas do dirigente comunista são esteticamente pouco interessantes. "É como se a verdade - ou as certezas - da posição bolchevique não emitissem a luz que a composição artística esperava delas. Ou, invertendo os termos, como se a composição estivesse pedindo a seu material o que ele não podia dar" ${ }^{\prime 85}$. O problema, aí, é o da relação entre, de um lado, a teoria revolucionária e o discurso político que dela deriva, e, de outro, o mundo ao

\footnotetext{
${ }^{83}$ A manipulação do conteúdo para a realização da forma não é um problema exclusivo dos produtos da cultura de massas nos quais os interesses econômicos aparecem mais evidentemente, e que são direcionados às multidões de consumidores. A cultura burguesa clássica, em seu processo de decadência irreversível, teve, por razões lógicas, que trilhar esse mesmo caminho. Em seus romances tardios, Thomas Mann, deparando-se com a falência da sociedade burguesa cujas estruturas alimentavam o drama, desenvolveu métodos muito pouco sutis de controle do material, de modo a dar sobrevida a uma forma que já era socialmente impossível.

84 R. Schwarz: "Altos e baixos da atualidade de Brecht" in Seqüências Brasileiras. São Paulo: Companhia das Letras, 1999. A contextualização de Brecht dentro do teatro brasileiro e as considerações sobre engajamento desenvolvidas nesse texto detalham alguns aspectos das análises empreendidas no "Cultura e política, 1964-69" in O pai de família e outros estudos.

85 Idem, p. 134. A fala do dirigente comunista a que Schwarz se refere está em B. Brecht: A Santa Joana dos Matadouros. São Paulo: Paz e Terra, 1996. pp. 127-8.
} 
qual essa teoria se dirige. Aquele discurso não consegue penetrar concretamente o conteúdo do texto teatral que é objeto da experiência estética, porque aquela teoria - devido às já comentadas alterações com respeito ao papel da crítica imanente no capitalismo - já não tem mais relação interna com os elementos da realidade que o texto mobiliza esteticamente $^{86}$.

Fica claro que, embora passe por uma crítica da representação, uma objeção de inspiração adorniana à positividade do pensamento (político) depende de uma análise histórico-sociológica, da qual, de fato, a crítica da representação é uma parte. Dessa relação com a especificidade de um momento histórico - com sua forma econômica e ideológica - não se pode sacar uma injunção política direta e imediata, como aliás é desenvolvido justamente naquela crítica da representação. Por outro lado, a relevância política do pensamento adorniano não é de desprezar. Há nele, tanto através da noção de pensamento da identidade, quanto das considerações sobre a imbricação contemporânea entre razão e violência, uma crítica radical da forma-mercadoria - desse produto de uma produção que, desde sempre, visa não a satisfação de necessidades, mas a troca. A percepção e exibição de como o princípio lógico da forma-mercadoria determina de maneira absoluta a experiência espiritual - da reflexão filosófica à criação artística fecha o caminho para as posições que tentam pensar em formas de tornar viável a vida sob o capitalismo por intermédio da interferência do discurso. O pensamento adorniano permite sentir o peso específico da forma corrente econômica de reprodução social e sua presença destruidora na totalidade das relações sociais, pedindo por posições que atinjam a dimensão econômica radicalmente e, portanto, projetando uma política que não se pode dar por satisfeita exceto quando a possibilidade de acabar com o capitalismo apareça em seu horizonte. As concepções reformistas também são barradas pelo pensamento adorniano, cuja tradução do poder desmesurado do capital contemporâneo - com seu aparato militar e ideológico - é a de uma derivação lógica dos princípios fundamentais da acumulação capitalista, de modo que a incorporação sistemática da violência na vida civilizada que

\footnotetext{
${ }^{86}$ Schwarz não deixa de fazer, no mesmo texto supracitado, uma breve história das relações entre 0 pensamento político revolucionário e a evolução do capitalismo, na qual o presente autor foi buscar muitas inspirações para as presentes considerações.
} 
hoje impera não consiste num desvio de rota ou num erro de cálculo, mas no exercício pleno dos potenciais intrínsecos das relações capitalistas de produção. Ademais, a concepção de experiência, o conceito de dominação, e o conseqüente movimento peculiar que Adorno impinge à dialética entre a parte e o todo, sugere uma insistência em que o sentido da práxis brote das próprias relações entre aqueles que a promovem, as quais precisam adquirir seu sentido em oposição àquilo que lhes é imposto desde cima, de modo que não há espaço para autoritarismo ou populismo mas, ao contrário, um aparato teórico que aponta para movimentos sociais de base ampla e ativa. Diante dessa crítica, aquele que busca uma inspiração política precisa encontrar, na condenação teórica irrestrita da sociedade da mercadoria, a possibilidade de reconhecê-la em sua brutal totalidade, e a necessidade de negá-la concreta e irrestritamente. 


\section{Referências:}

ADORNO, T. W.: Resignation in Telos no. 35. Tradução: W. Blomster, pp. 165$168,1978$.

Aesthetic Theory. Tradução: R. Hullot-Kentor. University of Minesota Press: 1997.

. Gesammelte Schriften. Frankfurt am Main: Suhrkamp Verlag, 1986. . Minima Moralia. Tradução: Luiz Bicca. Rio de Janeiro: Ática, 1993. . Negative dialectics. Tradução: E. B. Ashton. London: Routledge, 1973. . The schema of mass culture in BERNSTEIN, J.: The Culture Industry: Seclected Essays on Mass Culture. London: Routledge, pp. 61-96, 1991 . The Philosophy of Modern Music. Tradução: A. G. Mitchel e W. V. Bloomster. London: Sheed and Ward, 1973.

. Trois Études sur Hegel. Tradução: E. Blondel et alii. Paris: Payot, 1979. ADORNO, T. W. e HORKHEIMER, M.: Temas básicos da sociologia. Tradução: A. Cabral. São Paulo: Cultrix, 1973.

. Dialética do esclarecimento. Tradução: G. A. de Almeida. Rio de Janeiro: Jorge Zahar, 1985.

ARANTES, P. E.: Zero à esquerda. São Paulo: Conrad, 2004.

EAGLETON, T.: Capitalism, Modernism and Postmodernism. New Left Review I/152, pp. 60-73, July-August 1985.

HEGEL, G. W. F.: Ciencia de la logica. Buenos Aires: Solar, 1968.

. Encyclopédie des sciences philosophiques en abrégé. Tradução: M. de Gandillac. Paris: Gallimard, 1970.

. Fenomenologia do Espírito. Tradução de P. Meneses. Petrópolis: Vozes, 2001.

LUNN, E.: Marxism and Modernism. London: University of California Press, 1982.

MARX, K.: Capital: Volume I. Tradução: B. Fowkes. London: Penguin Books, 1990.

. Capital: Volume III. Tradução: D. Fernback. London: Penguin Books, 1991.

. Teses Contra Feuerbach. Manuscritos Econômico-Filosóficos e outros textos escolhidos. Tradução: J. C. Bruni et. alii. São Paulo: Abril Cultural, pp. 49-53, 1978.

. Crítica da Filosofia do Direito de Hegel. Tradução: R. Enderle e L. de Deus. São Paulo: Boitempo, 2005. 
OEHLER, D.: O Velho Mundo Desce aos Infernos. São Paulo: Companhia das Letras, 1999.

OLIVEIRA, P. R. de.: Dialética Negativa como Perspectiva para o Pensamento. PUC-Rio, Departamento de Filosofia: 2005.

POSTONE, M. e SANTNER, E.: Catastrophe and Meaning. London: University of Chicago Press, 2003.

SCHWARZ, R.: O pai de família e outros estudos. Rio de Janeiro: Paz e Terra, 1978. . Seqüências Brasileiras. São Paulo: Companhia das Letras, 1999

TROTSKY, L.: The Struggle Against Fascism. New York: Pathfinder Press, 1971

Email: oliveira.rocha.pedro@gmail.com

Recebido em: Abril de 2011

Aprovado em: Maio de 2011 